Portland State University

PDXScholar

1974

\title{
The Recognition, Investigation, Interpretation, and Treatment of Landslides in the Pacific Northwest
}

Harry Ludowise

Portland State University

Follow this and additional works at: https://pdxscholar.library.pdx.edu/open_access_etds

Part of the Earth Sciences Commons

Let us know how access to this document benefits you.

\section{Recommended Citation}

Ludowise, Harry, "The Recognition, Investigation, Interpretation, and Treatment of Landslides in the Pacific Northwest" (1974). Dissertations and Theses. Paper 2179.

https://doi.org/10.15760/etd.2176

This Thesis is brought to you for free and open access. It has been accepted for inclusion in Dissertations and Theses by an authorized administrator of PDXScholar. Please contact us if we can make this document more accessible: pdxscholar@pdx.edu. 
AN ABSTRACT OF THE THESIS OF Harry ludowise for the Master of Science in Geojogy presented Mey 13, 1974.

Title; The-Recognition, Irvestigation, Interpretation and Treatment of Landslides in the pacific Northwest.

APPROVED BY NEMBERS OF THE THESIS COMMTTEE:
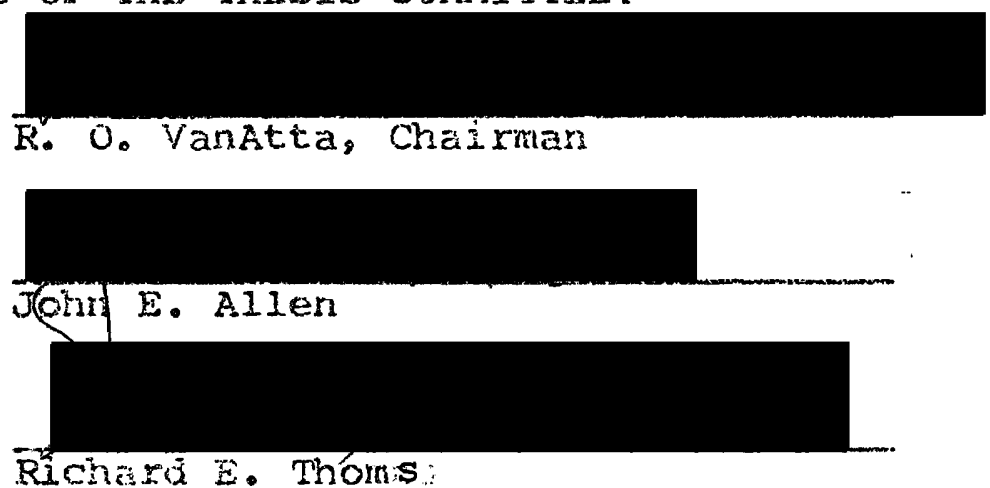

Cextain features unique to the pacific Northwest intuence landsliding in this region, Weakly consolin dated sediments, derse vecetation ard seesually concentrated raingald a 13 contribute to the distinctive concitions tint are encountared here.

mis study gathers together information appiying to the peogrition and correction of padiate forthivet landsudes. Treatment practices common to tha Eogion axe discusssa.

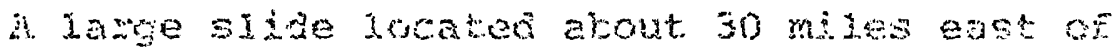

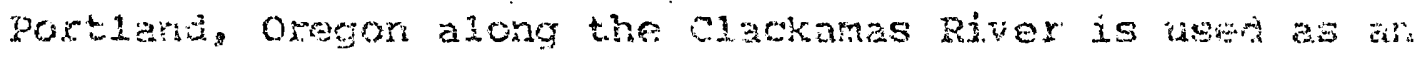

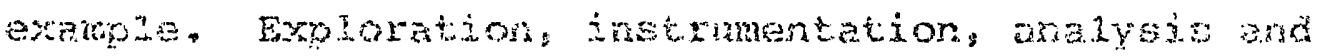

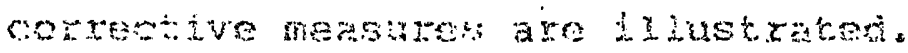


THE RECOGNITION, INVESTIGATION, INTERPRETATION

AND TREATMENT OF LANDSL IDES IN THE PACIFIC NORTHWEST

by

HARRY LUDOWISE

A thesis submitted In partial fulfillment of the requirements for the degree of

\author{
MASTER OF SCIENCE \\ in \\ EARTH SCIENCES
}

\author{
Portland State University \\ $197 \dot{4}$
}


TO THE OFFICE OF GRADUATE STUDIES AND RESEARCH:

The members of the Cormittee approve the thesis of

Harry Ludowise presented
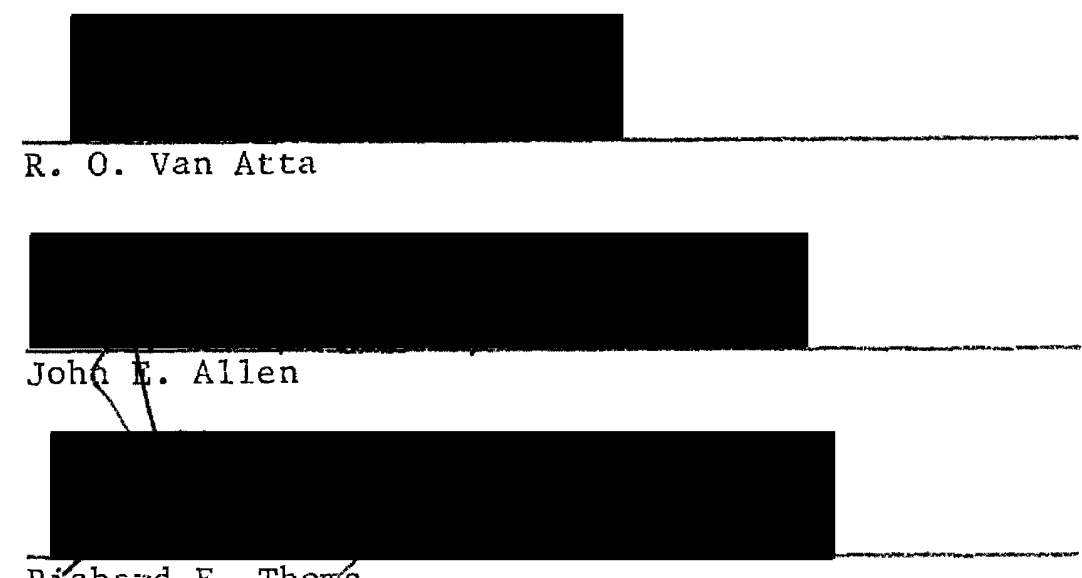

APPROIETJ:

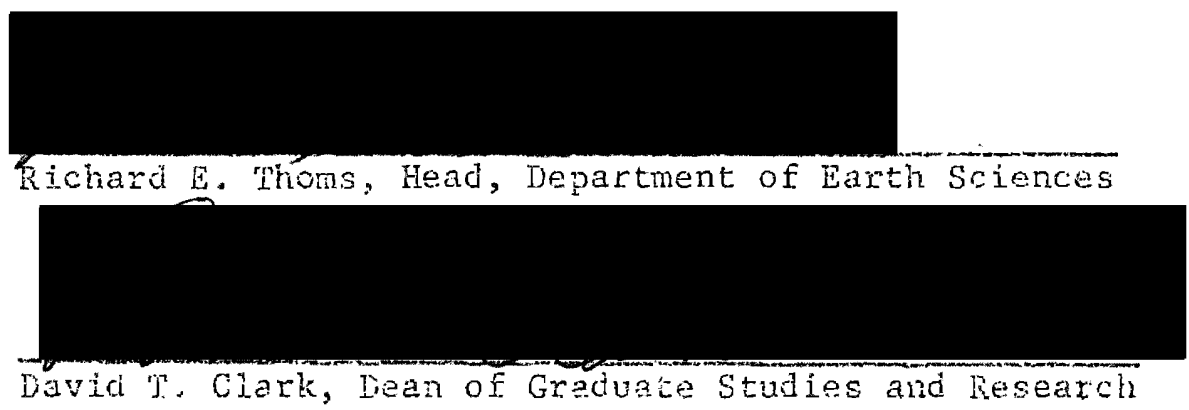


TABIE OF CONDENTS

PACI

IIST OF TABLES .....................

IIST OF FIGURES . . . . . . . . . . . . . . . vi

IIST OF PLATTSS . . . . . . . . . . . . . . . vii

CEAPTER

I INTRODUCTION ................ I

Purpose ................... 1

Definition and Classification of Landslides . 2

Pacific Northwest Slides ......... 3

Economic Significance of Landsides ..... 4

II RECOGNITION OF LANDSLIDIS . . . . . . . . . 7

Evisting Data ............... T

Recomnaissance ............. 9

IIT INYESTIGATION OF ILARDSLIDES ........... 10

Preliminary Investigation .........

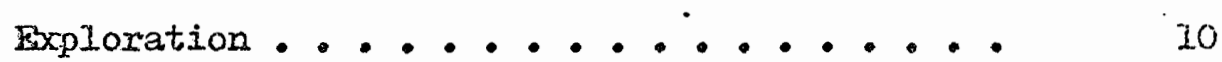

IV IFIEREPRETATION OF FEXIORATION AND STABILITY

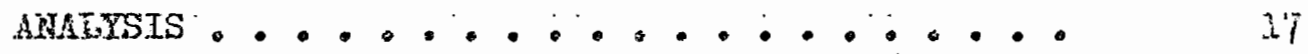

Analysis Draing Exploration ....... . I?

Jaboratory lests and Selection of Strength

Values .................. 18

Stabizity Anazysis ........... 18

Stability of Sidiag Slopes . . . . . . 25 
V TREATMENT OF IANDSLIDES . . . . . . . . 28

Preliminary Remedies . . . . . . . 28

Permanent Treatment of Slides ...... 30

Aroidance

Reducing the Driving Forces

Increasing Shearing Resistance

VI CLACKAMAS LANDSLIDE ...............

Introduction .................

Background . . . . . . . . . . . .

Exploxation ................

Laboratory Testing ............

Stebility Analysis.............

Cosrection

Corclusions ................. 


\section{IIST OF TABLES}

$\begin{array}{ll}\text { TABLE } & \text { PAGE }\end{array}$

I Laboratory Data Clackamas Landslide ............. 52 
IIST OF FIGURES

FIGJRE

PAGE

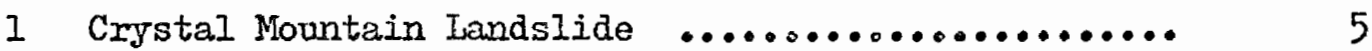

2 Landslide Analysis using the Method of Slices ...... 22

3 Calculation of Force from Water ................ 24

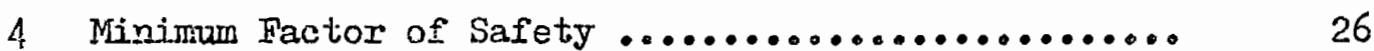

5 Drainage Methods ......................... 35

6 Restraining Methods .......................... 40

7 Station 425 Clackamas Highway Slide ............. 48

8 Wedge Analysis ............................ 53

9 Corputer Analysis Clackamas Highway ............. 55 
LIST OP PLATES

PLATE

PAGE

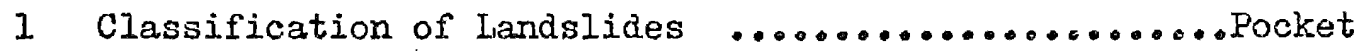

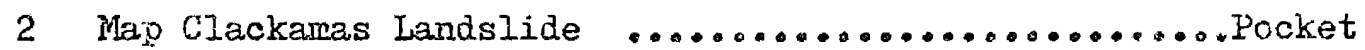

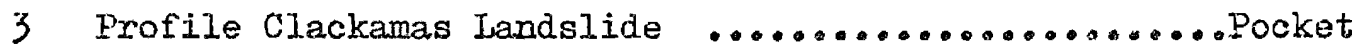




\section{CHAPTER I}

\section{INPRODUCTION}

Landslide problems are especially acute in the Pacific Northwest due to the rainy climate. Rainfall concentrated during a few months in the winter causes saturation of the ground, triggering landslides. Pacific Northwest landslides cause several hundred thousand dollars worth of damage annually (Schlicker, 1956). The actual cost in undoubtedily higher than this because much damage is unreported. The Coast Range lountains are particularly landslide prone due to high rainfali and poorly consolidited sediments. Nearly every major highway cut in these nountains has experienced some slide problems.

$$
\text { I. PUPROSE }
$$

The purpose of this study is to prepare a guide to recognition, investigation and treatment of landslides in the Paciric Northwest. This study collects and reports information and data that relate to this area from the large volume of material available on landsiddes. A Jocal landslide has been utilized as an example of applied investigation and. treatment. There are many large slides in this area which are too massive to treat, but it is important to recognize them because frem quently a troublesome small slide is merely a reacisvation of a portion of a much larger pre-existing slide. 


\section{DEFINITION AND CILASSIFCCATION OF LANDSLIDES}

The Highway Regearch Board, Special Report No. 29, 1958, defines a landslide as follows: "A landslide is the downwaid and outward movement of slope forming materials, composed of natural rock, soils, artificial fills, or combinations of these materials." Landslide movement majy be rapjd, as in the case of an avalanche, ${ }^{1}$ or the movement may be much slower, taking, place over a period of days or even months. The rate of movement in a landslide usually accelerates from zero or a small value and then again slows to a nomiral value. In contrast, creep is a slow but relatively constant rate of intermittent movement taking place over a pexiod of years or decades. Creep phenomena and landsilding have gradational boundaries and may be difficult to differentiate in actual practice.

(A number of classification schemes have been proposed by various authors (Terzaghi, 1950; Sharpe, 1938). These classification schemes. have been based on the material involved, the shape of the slip surface, or the speed of movement. Terzaghi (1950) has stated. "A phenomenon involving such a multitude of combinations between materials and disturbing agents opens wisimited vistas for the classification enthusiast.") In genera], most classification systems have suffered from over complexity so that people in the field never learn enough about a yarticular slide to properly classify it. Regardless of tine dufficulties involred, it is still. necessary to have some system so that a slide

\footnotetext{
The term evalanche as used in this report refers to the speed. of movernert and does not imply a composition such as snow.
} 
.may be described easily. The classification that will be followed here is one proposed by vames, at present the classification most widely accepted (HBB Bull. 29; 1958).

Landslides may be initiated or former slides may be reactivated by human activity. The connection between human works and landsliding may be immediately obvious where earthwork is inrolved, or it can be a less direct connection where deforestation or the construction of a subdiviston bas changed the ground water pattern and underground drainage.

Jand̉slides are frequently studjed from two different approaches: that of the geomorphologist who is interested in landsliding as axs agent in slope recession and erosion, or from the point of view of the enginosing geologist who is interested in the impact of sliding on man's works and methode of miniroizing resulting damage.

Actaaliy, landalides can best be studied and described by using both approaches to recognize the causes and effects of slinting. Iand slides which are not anticipated or evaluated in advance frequently destroy property which may cost many thousands of dollars as weli as endanger haman lives.)

\section{PACIFIC NOR'HHWST SLIDES}

There are a number of najor slides in the Pacific Northwest which are ejther large enough or have had sufficient ecoromic initact to have been reported in literature. The Sitkun slide in southutestern Oreeon, which resulted in the formation of a lake and caused the deposition of several square miles of lacustine deposits, is an example (Balowin, 1964). In addition to the wajor slides, there ane 
large numbers of smalier landslides of al. types.

C Conditions in the Pacific Northwest that favor landslides are steep terrain, poorly consolidated sediments or sediments with expandow able clay content, and high rainfall. The effect of the rajnfall is multiplied by the fact that the rain is seasonally concentrated during nine months of the year. These conditions result in a type of rapid moving slide which may be distinctive to the Pacific Northrest. These slides consist of mud containing up to as much as 50 to 60 percent logs and other vegetative debris. These fast moving slides usualiy are formed in small draws containing intermittent streams. The intermingling of soil and logs remaining after one of these slides is especially difficult to clean up. Because these slides move rapidly, they can be very hazardous and destructive.) Examples of this type of. slide include the one which destroyed the $U$. S. Post Office in lapletong Oregon on January 28, 1965. A similar slide clesed the robd Leading to the Crystal. Mountain ski area in Washington on July 16, 1971. (Fisure 1). Ihese slides are unique because their high debris content seens to help retain the moving material in a compact mass with a high liguid content. The remains of this type of slide can easily be mistaken for a log jam caused by a stream because ance motion has stopped, the sojil and water drain away leaving only the logs.

\section{FCONOMIC SIGNIFICANCT OR IANDSIIDES}

Several hundxeds of thousands of doliars axe expended anrually on blides in the Pacific Noxthwest (Schlicker, 1956). Many slidea are cleaned up and repaired by the persons or agercies inmediately involved and no xecords of the costs are maintained, so the cost is undoubtedly 


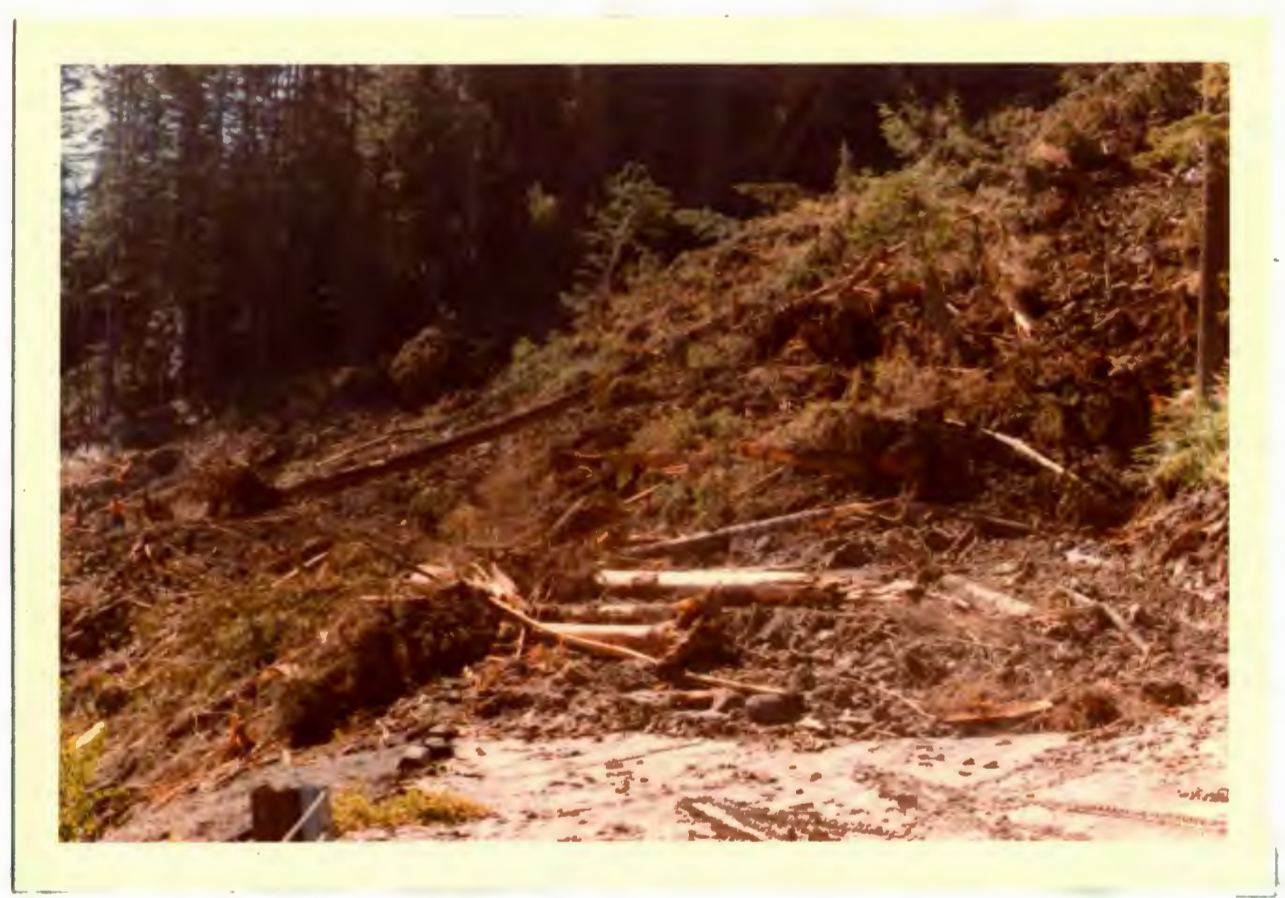

Figure 1. Crystal Mountain Landsiide. Note the high debris content. 
larger than that recorded. However, the magnitude of the problen is indicated by the following example. In the Impqua National Forest, the slides which were large enough to require a contract to correct, cost approximately $\$ 156,000.00$ in $1971 .^{2}$ This figure does not include any of the smaller landslides which were cleaned up under timber sale contracts or by maintenance forces, nor does it include slides which occurred on Burean of Iand Management roads and state highways or on private property.

A single slide can vary widely in cost depending on the size. An example of a large slide is one located about one mile north of Port Angeles, Washington on the "Heart 0 ' the Hills Road" in the Olympic National Park which cost approximately $\$ 760,000,00$ to correct. $^{2}$ This figure does not include the mount expended on exploration and design. There are indirect costs involved in landslides, including fxtra engineering on current construction projects, extra right-of-way costs, distration of traffic, dislocation of utilities and many other side effects for which no cost accounting is made. Attempts have been made to evaluate the costs of landslides but there are so many factors and agencies involved that they will probably never be accurately measured in terms of dollars. The loss of human life and the interruption of normal commerce would make the cost even greater than a simple addition of damage costs.

${ }^{2}$ Pecoxds Federe. Highway Administration, Vancouver, Washington, 
CHAPTER II

\section{RECOGNITION OF ILANDSLIDES}

(Landslides are especially difficult to recognize in the westerm part of the Pacific Northwest due to the almost universal prevalance of thick vegetation. In the Coast Range Mountains, the understory vegetation is frequently so thick that one cannot see nore than a few feet in any direction, and therefore, the physical phenomena associated with lanảslides are difficult to identify.

(If an investigation is to be part of a study for engineering work where new constmuction is to be involved, a preliminary investigation is essential.) This includes a study of aerial photographs and a review of any literature which pertains to the area. In general, there are a few parts of the Pacific Northwest where one govermment agency or another does not have photographic coverage. The topography, soil types and geology can be evaluated before embarking upon any field work. A good preliminary study will not eliminate any part of the necessary field investigation, but will make it easier to accomplish and more effective.

\section{EXISTING DATA}

Good sources of literature and information on 3 particular area of interest include maps and other pubiications of the United States Geological Survey. State geological surveys also commonly produce maps and publications which prove to be of value in investigating an area for potential landslides. Many of the newex maps may actually show areas 
of old landsliding. Utility companies, railroads and highway departments sometimes have unpublished reports which contain useful information. In addition to these sources, soil survey maps and bulletins published by the U. S. Department of Agriculture in cooperation with the states are excellent sources of information. U.S.D.A. soil bulletins published from 1958 to 1961 often contain a section on engineering applications, and after 196], all the soil bulletins contain a section on the engineering characteristics of soil types. To be of greatest value in identifying landslides, aerial photographs shoula be of a scale close to 1 to 10,000. A landslide must be relatively large to show up on a photograph with a scale of 1 to 20,000 or larger. Some of the features that can be discovered on an aerial photograph which help identify a potential landslide are steep slopes, changes in vegetation, the semicircular scar of the head scarp, and disturbed ground with humocky topography and undrained depressions. Evidence of ground movement also can be detected from aerial photographs such as displacement of a creek to one side of its channel by the encruaciment of slide debris into the creek (HRB Bull. 29, 1958).

The majority of landslides which must be corrected are small, less than 100 feet in width and length, and these will barely be distinguishable on a photo with a scale of 1 to 10,000. Because of this, aerial photos may be of the greatest assistance in locating areas prone to sliding ratker than for spotting each individual slide. Photos should be consil ted whenever available to assure the investigator that the active slide he is working with is not just a small part of a larger mass that is difficult to identify on the ground. 


\section{RECONNAISSANCE}

Iandslides can be recognized on the ground by the same features which are identified on aerial photographs. In addition, an on-the-spot reconnaissance will often uncover features which are too small to be identified on an aerial photo, or are masked by heavy vegetation. Many slides are difficult to detect on the ground because of their large size, and close attention to details on the photos is necessary to detect them. One of the more common landslide features which is useful in detecting large slides on the ground is the soil type. Large slides often contain a heterogeneous mixture of boulders, cobbles and fine grained soil, similar to glacial till (Crandell, 1971). Outcrops of rock should be checked and the attitude of the bedding should be compared with the regional attitude. An explanation should be sought if discordant attitudes are found. Jendslides can be detected by noting the presence of water-loving vegetation, displacement of linear features, bowed or bent trees, undrained depressions, cracks, scars, and other features normaily associated with landsliding such as hummocky ground (HRB BuII. 29, 1958). While none of these features are conclusive in themselves, they furnish a clue that a further investigation on the ground is desirable in search of supporting and confirming evidence for the existence of a landslide. Unless massive earthwork has covered it, there is almost always evidence of premexisting unstable landslide conditions. . Some of the most troublesome and costly slides are the result of reactivation of an older slide mass. In the author's experience, the presence of a number of small slides are indicative of a potential of larger landslide activity. 
CHAPTER III

INVESTIGATION OF IAANDSLIDES

\section{PRELTMINARY INVESTIGATION}

The most satisfactory time to recognize a landslide problem is during the preliminary ground reconnaissance which is normally conducted for any significant engineering project. At this stage, plans are uspally still. tentative in nature and little has been invested in the location. Recognition of a slide problem at this stage can often result in relocation to avoid the problem, or the design can be easily altered to provide for the landslide. The more advanced the plazaning, the more difficult and costly it becomes to make modifications; therefore early recognition of landslide problems is vital for a safe and. economic design of engineering works.

\section{EXPLORATION}

One of the first steps in the field exploration of a landsilide is preparation of a map and crossmsections. The purpose of mapping at ain eaxly stage is to provide a working base on which the exploration data can be located and plotted. Maps which are prepared for slide investigation generally contain both aerial and geologic data. One of the first decisions which must be made is the map scale and contour interval. The area to be mapped, the importance and extent of the study as well as the physical topography, will bave a bearing on the scale and contour 
interval selected for use in mapping. A scale frequently used by engineers is 1" to 100'. This scale will be found useful in a Ereat many slides. If buildings are involved or great detail is to be mapped, a scale of $1^{\prime \prime}$ to $10^{\prime}$ or $1^{\prime \prime}$ to $50^{\prime}$ may be the best scale. Slides which cover large areas, such as a square mile or more, may require the scale to be $1^{\prime \prime}$ to $500^{\prime}$ or $1^{\prime \prime}$ to $1000^{\prime}$ in order that the entire slide may be included on a single sheet of usable size. The contour interval may be any appropriate to the topography and may range from $2^{\circ}$ up to $50^{\circ} . \Delta$ suggested contour interval for the average slide is 5' (Zaruba and Mencl, 1969)。

A landslide vicinity map should contain references to: property lines, bench marks, stationing on a highway or railroad or other recognizable permanent features; special slide features such as cracks, displacement of fences and any other landslide features; cultural features such as roads, buildings, fences, pipe lines and sewer lines; any possible water sources including streams, rivers, creeks, and ponds; and subsurface investigations such as drill holes, test pits, instmunentation location and the location of geophysical tests.

When exploring a landslide, one of the most important parameters which must be determined is the shape and configuration of the slip plane. Investigators are discovering, with the increased use of inclinoneters: that the slip plane is nore complex than had previously been believed. In fact, the simple rotational failure may exist only in small slides involving a few hundrea cubic yards (Stout, 1971). The chief use of slip plane data is in analysis and correction design. There are several methods which can be used to deternine the depth 
and shape of the slip surface. The one most frequently used in the preliminary and reconnaissance stage is inference based on the physical appearance of the slide. This method can be refined by inclusion of actual measurements of the attitudes of the cracks at the head of the slide and the slip surface at the toe. These are plotted on a profile and are then connected wi.th a smooth curve. The result is often a reasonably accurate representation of the slip surface which can be shown on the cross-sections (HRB Bull. 29, 1958).

The combination of inspection and physical measurement may seem to leave a great deal of latitude for personal evaluation, but in actual practice the results are satisfactory and, in most cases, experienced engineering geologists often arrive at almost identical profiles when working on the same slide (ARB Bull. 29, 1958). This method of determining the slip surface has the advantage of being rapid and relatively inexpensive because it utilizes the equipment that most geologists will have with them in the field - the hand level, tape and Brunton compass, Borings are frequently made to investigate a landslide. When arranging a program of borings, it is best to include as many auger borings as possible so that water-bearing strata infornation can be obtained along with the rest of the data. The slip plane is usually difficult to detect in borings unless the slip is occurring along a change in soil or lithology. The slip surface is sometimes associated with a water flow, 3 yoint helpful in identifying the slip surface in the boring. Continuous sampling is often resorted to, if there is no change in texture or lithology. The sip surface can appear as a thin parting in the soil and is easily overlooked. On rare occasions, the 
boring is made large enough to allow a man to descend down the bore hole and actually observe the strata (Leighton, 1966). The major problems with borings are that they are expensive, access is often difficult for equipment, and the slip surface is frequently orerlooked in a bone hole.

Geophysical methods, primarily resistivity and seismic refraction are sometimes applied to a landslide in order to determine the slip surface. Earth registivity is particularly useful in this regard if the slide is recent or still moving. A series of resistivity depth sounding cross-sections are taken at intervals down the length of the slide, nomal to the direction of the movement. These tests, when plotted on a profile of the slide, often reveal the depth of the slip surface (Moore, 1965). The earth resistivity technique is very sensitive to changes in resistivity along with depth. This test is advantageous in that the surface area needed to make a test is roughly three tizes the depth of interest so that it can be conducted on a namrow slidie.

Another phenomenon, which is as yet unexplained and is sometimes encounteres when conducting resistivity tests on an active landslide, is an electrical disturbance associated with the slip surface. This disturbance is recorded on the resistivity depth test as a sharp displacement of the field curve (Moore, 1965). The electrical disturbance gradually decreases with time after the sidde has come to rest. In the author's experience, the terts must be conducted within the month in which the wide movement occurred in order to be successful in detecting this electorisin dishurbance. 
Refraction seismographs have also been utilized in order to detect the slip surface when there is an increase in velocity associated with with it. Refraction seismology has the disadvantage that the spread on the surface must be four to ten times the depth of interest. This often results in the line, along which geophones are placed, extending beyond the slide onto non-sliding ground.

Various well logging techniques such as electro logs and gamma logs might also prove valuable in determining the slip surface in a slide. There has been little reference to the use of these methoàs in literature on the study of landslides. The slip surface frequently contains extra moisture or a change in lithology. Well logging techniques respond to both of these changes so that detection of the slip plane by these methods is a definite possibility.

Inclinometers of various types are frequently installed in active landslides to detect the siip surface. These range from a simple tube down which rods can be lowered in a boring, to instruments costing over $\$ 10,000.00$. The use of these inclinometers is limited by two factors: they must be installed in a bore hole and the slide must still be active. The inclinometer measures deformation of a casing which has been placed in the slide. This property is probably the most serious disadvantage because in many cases involving engineering work, the slide must by analyzed and a correction designed before any movement occurs or can be detected. Many slides do continue to make slight movements which can be picked up by a sensitive inclinometer even after the surficial movement has apparently ceased. An additional problem has been that inclinometers usually require the installation of a relatively 
large tube that drills commonly available could not install. This problem has been solved recently and several commercially available units will fit inside a 2" diameter tube (Dunnicliff, 1971).

An example of an inexpensive inclinometer is a simple tube, usually of electrical conduit or plastic tubing. Different lengths of rods are lowered inside the truing and the length of rod just able to pass through the bend in the tube can be related to the degree of curvature of the tube. This system has the advantages that it may be assembled in the field from materials which are available in any hardware store and that few calculations are needed to analyze the data. The disadvantage is that this simple and inexpensive type costs nearly as much to install as the more sophisticated inclinometers, since the primary cost of installation is in boring the hole and backfilling around the tube. In addition, this type has a low order of sensitivity to detect minor movements and is unable to detect multiple slip surfaces. This last problem can be partially overcome by leaving a rod in the bottom of the tube attached by a wire and measuring from both the bottom up and the top dowr. The Oregon Highway Department has used an improved simple inclinometer, a square tube, which gives better orientation. They have purchased a strain gauge inclinometer which fits the same tubes.

More sensitjve and precise inclinometers have been manufactured using various systems including photographic, pneumaic, the Wheatstone bridge, strain gauge and the accelerometer as the principle of operation. The better models of these instruments are capabie of detecting deformations in the casing in the order of $1^{\prime \prime}$ in 1000" (Dunnicliff, 1971 ). 
Sensitive inclinometers usually have the disadvantage that some calculations must be made before the data can be utilized. Computer programs are available which accomplish these calculations, but if the computer is used, the results will not be immediately available in the field. Most inclinometers also take some time to read in the field since a profile of the entire tube is normally developed. This is accomplished by making readings at some set interval, usually $2^{\prime}$. Some instruments require a positive and negative reading in each direction so four traverses of the tube are required if both the east- west, north-south components of the movement are desired. It normally takes 30 minutes or more to read a tube, depending on the depth of the tube and whether both directions of movements are desired. The results are then reduced and compared with the initial readings which were taken on each tube. This comparison can be done by superposition of the two plots on a light table ox the comparison can be made directly in the computer program which reduces the data and prints out the differences between the two sets of readings (Dunnicliff, 1971). 
CHAPTER IV

INTERPRETAMION OF EXXLORATION AND STABIIITY ANALYSIS

\section{ANALYSIS DURING EXPLORATION}

It is essential that interpretation and analysis be carried on during the entire process of landslide investigation. Iuring the field exploration, new data should be utilized as soon as obtained. Ii is often advantageous to change the exploration plan from that originally proposed and maximun information from each boring is essential (HRB Bu11. 29, 1958).

A vicinity map and cross-sections should be prepared early during the slide investigation processes. All information from drill holes and other sources should be plotted on the map and cross-sections as soon as obtained. Interpretation of the geological information, geophysical results, boring information and laboratory test data is the most demanding part oi a landslide study. The success of mathematical solutions and the design of corrective measures depend on the selection of the proper slip plane configuration and the proper soil strength parameters from test data. Where have been a number of studies on the selecti.on of strength parameters for stability analysis. Experienced jadgment is still of primary importance in the selection of the proper values (Schuster, 1967), (Singh and Lee, 1970). 
II. IAABORATORY TESTS AND SELECTION OF STRENGTH VALUES

Laboratory testing of cohesive soils has reached a fairly high state of reliability, but landslides are frequently composed of heterogeneous mixtures of soils, and if a number of samples are submitted for testing, a range of values may be received from the laboratory. The type of slide will also have a bearing on the type of laboratory tests run which in turn will have an effect on the values received (Bishop and Eenkel, 1964). The formations in the slide will. also have an effect on the choice of strength values to be used in analysis. In a fissured clay, for example, the strength of the clay is largely determined by the fissures which are not examined in the sma.ll laboratory sample and the laboratory values must be dexated by a factor of 5 to 10 (Terzaghi, 1936). The effects of time must be considered in the choice of strengths and the type of analysis performed (Skempton, 1948).

\section{STABIIITY ANALYSIS}

There are a number of methods available to analyze landslides. many of which have been adapted to the use of the electronic computer. Most of the rethods of landslide analysis are based on the assumption that the shearing strength of any soil is made up of cohesion and internal friction. The Swedish method of slices was developed by Fellenius (I927) and has remained the basis of most of the analytical methods applied to rotational slides ever since. The method of slices is a technique of breaking a large irregular mass into smaller units. 
The forces acting on these smaller units can then be calculated. This method remains the most common method of slide analysis today, even though it results in a slightly erroneous safety factor (Lambe and Whitman, 1969). The reasons for the continued wide use of the method of slices seem to be that it is videly known, simple to use, and the exrors are on the safe side. The Bishop method, a modification of the method of slices is considered by many authorities to be the rost accurate method of analysing the rotational type of slide (Bishop, 1955). Morgenstein and Price (1965) introduced a method of analysis which enables one to cope with an irregular slip plane. In many slide problems the slip plane can be approximated by a straight line or a series of lines. In this case, an accurate safety factor can be obtained by the wedge method. (Figure 8 ).

Another method of analyzing rotational types of slides is that developed by Taylor (1937). Students of landsidides noted when analjzing rotational slide failures that if the angle of the slope renained constant and the height increased, the failure arc would enlaxge in proportion. This being true, a factor could be developed for each angle of slope which would not be dependent on height. Taylor published a set of these factors which he called stability nambers. He also noted while analyzing the large number of slides in checking his data that there were relationships between the center of the most critical arc and his nambers.

Knowing the soil properties and the slope, one can enter his tables and find the most critical arc and the factor of safety. Capper and Cassie (1949) and NAVFAC DM-7 (1971) contain the necessary 
tables and directions for their use. This method is especially useful in the design of stable cut slopes in excavation. The tables can be entered with the soil properties and the proposed slope after which one can quickly determine if the proposed slope will. be stable.

The following is an example of slide analysis using the Swedish methad of slices. No attempt will be made here to go into the background or theory behind this method of analysis.

In order to make a stability analysis of a landslide, it is necessary to have the following information: (1) a definition of the soil mass involved, such as depth and lateral extent, (2) zones of weakness, (3) the strength parameters of the soils involved (weight in pounds $\zeta$, cohesion in pounds $C$, angle of internal friction in dedegrees $\varnothing),(4)$ pore pressure or ground water level, and (5) outside influences which may affect the slide, as irrigation or broken water and storm sewer lines.

Once this information has been assembled, the next stage in raking a stability analysis is to construct a cross-section of the slicie. The cross-section must be parallel to the direction of movement and at the point of greatest length of the slide. The actual cross-zection will be necessarily idealized doe to the complexity of most landslides as well as the paucity of information about the slide. If the analysis is to be done by computer, there may be reatrictions on the cross-section imposed by the computex program (State of Calif., 1970). If the computations are to be done manually, it will be advantageous if the number of soil layers ean be idealized to one layer or two, at the most. Once the cross-section is completed and the soll 
properties shown, it will be best to ink the drawing if the problem is to be solved by hand, so that construction lines can be penciled in and erased without destroying the cross section.

In oxder to save time in both hand calculation and computer time, if one is used, it is necessary to select an initial arc as close to the critical failure arc as possible. In a soil deriving most of its strength from intermal friction, a shallow failure arc will have the lowest factor of safety. When a soil derives most of its strength from cohesion, a deep failure arc will usually be the most critical (NAVFAC DM-7, 1971). In some cases, such as that of an embankment with a stabilizing berm, more that one critical arc may exist and it will be desirable to analyze the section using more than one initial failure center so that ail potential failures are located.

After laying out the assumed failure arc on the cross-section, the next step is to break up the mass above the failure arc into a series of vertical slices as shown on Figure 2 (Lambe and Whitman, 1.969). Six to ten slices is normally considered adequate. They need not be of equal width, but the boundaries shoild be drawn so that the slices form simple geometric shapes. Slices 2 through 6 can be treated as trapezoids and slices 1 and 7 as triangles. Once the slices have been drawn, and the original arc drawn, the next step is to lay out a table as shown on Figure 2. Different authorities may set up the table in different ways, but the resalts will be the same (Iambe and Whitinan, 1969), (HRB BuIl. 216, 1959), (Bishop, 1955). 


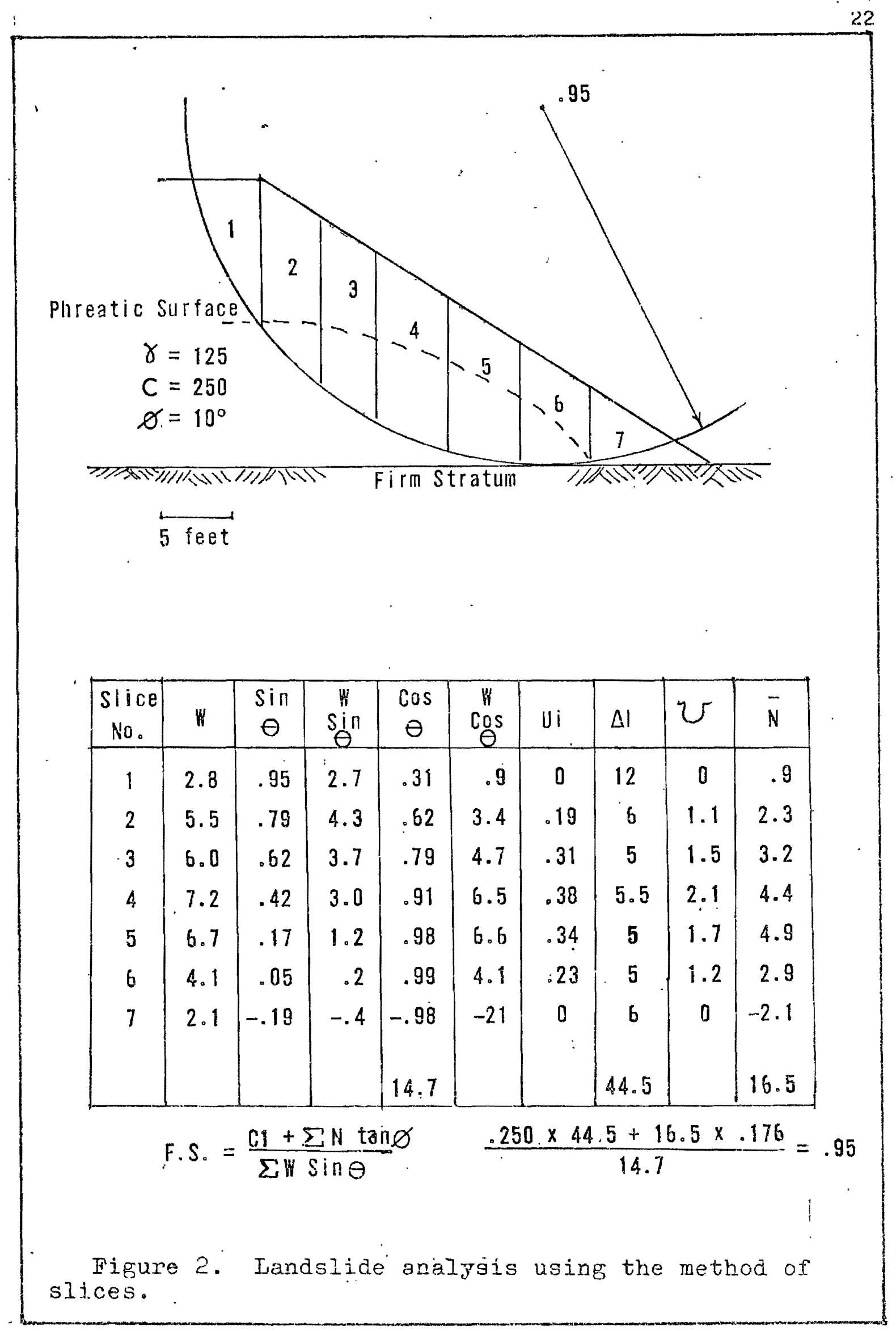


The table is filled in as follows: Slice Number - self-explanatory W - the weight of each slice, found by multiplying the area of the slice by the weight of the soil per cubic foot. This gives the weight of the slice as the slice is assumed to be 1 foot thick. $\sin \theta$ - the sin of the angle between the horizontal and a line normal to the radius of the failure circle. This angle is usually found graphically from the cross-section. $W \operatorname{Sin} \theta$ - tangential force of the slice; column $W$ multiplied by the sin.

$\cos \theta-\cos$ of the angle found for sin. $W \operatorname{Cos} \theta$ - normal force of the slice; column W maltiplied by the cos. Ui - the pore pressure; found by multiplying the depth in feet taken at right angles to the pbreatic surface from the bottom of the slice, times the weight of water or 62.4 (Figure 3). This column is not used if water is not present.

1 - the length of the failure surface along the bottom of the slice in feet; usually found by picking it off the graplu with a scale and assuming the bottom of the slice to be a straight line. $V$ - the force from water; found by multiplying length by Ui. This column is not usea if water is not present. N - the effective roxmal force; calculated by sabtracting the force from water $U$ from the effective weight of the slice $W \operatorname{Cos} \theta$. If pore pressure is unknown, or not a factor, the value of $W$ Cos $\theta$ is used.

Generally the weights found are recorded in thousands of pounds called Yips $(K)$ in ozder to simplify the note-keeping, but it does not 


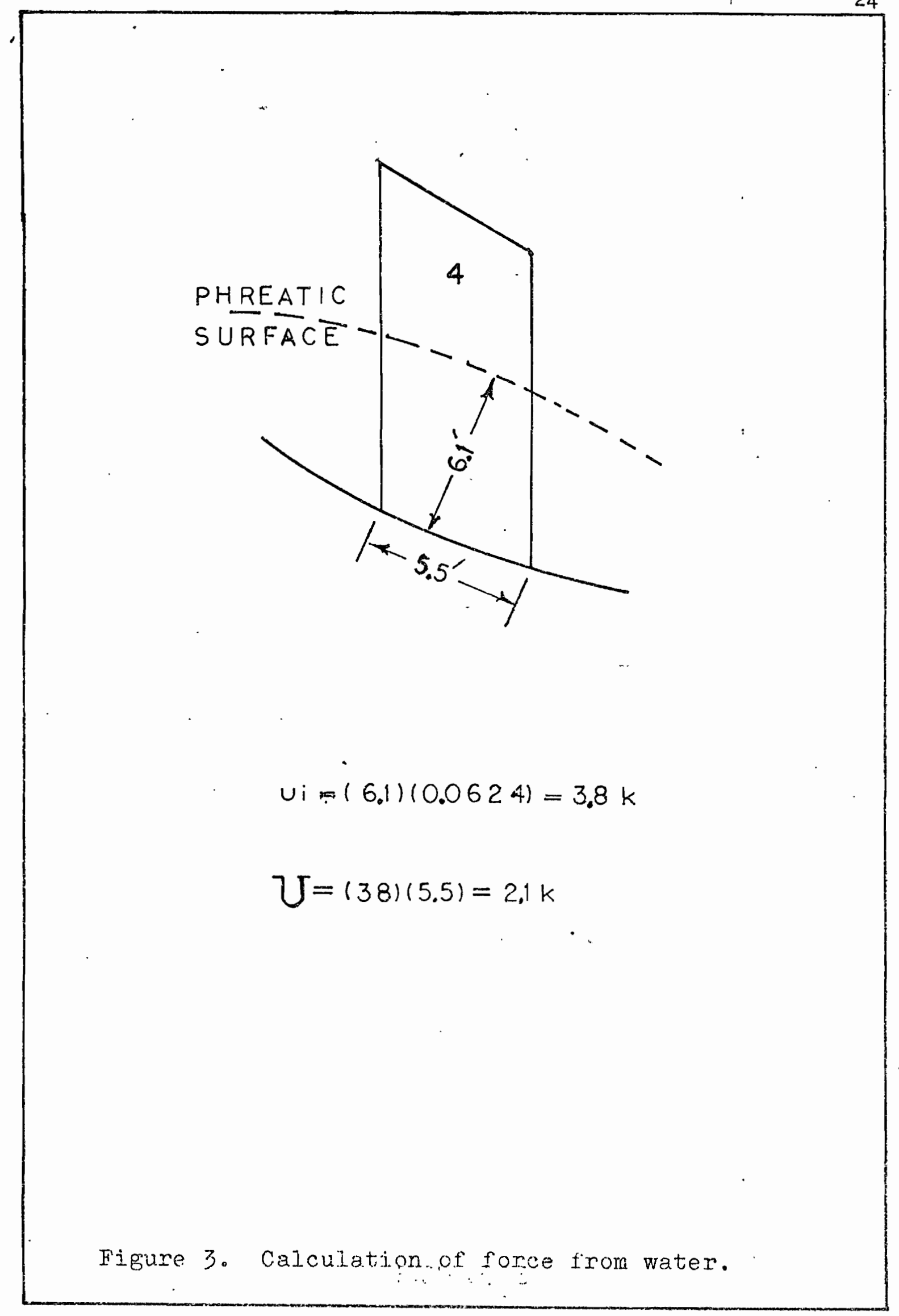


matter what units are used as long as they are used consistantly.

The final step is actually calculating the factor of safety for the arc. The factor of safety is defined as follows: the sum of the forces resisting motion divided by the sum of the forces actuating. If the actuating forces are greater than the resisting forces, the factor of safety falls below 1 , and the failure of the slope is imminent. The actual equation used to find the factor of safety i.s: F.S. $=\frac{C l+\Sigma N \tan \phi}{\Sigma W \operatorname{Sin} \theta}(\mathrm{HRB}$ Bull. 29, 1958). An example of the actual calculation is shown in Figure 2.

In order to find the minimum factor of safety for a slope, it will be necessary to calculate the factor of safety for several failure arcs. Since the center of rotation may move vertically and horizontally, and the radius may vary, it requires considerable judgment to know when the minimum factor of safety has been found. When there is a firm base to the slide, the circles are all drawn tangent to the base and the factors of safety are plotted as a grid, contovers showing equal factors of safety are drawn, and the minimum will thes show up as a depression (Lambe and Whitman, 1969). (Figure 4).

\section{STABILITY OF SLIDING SLOPES}

If the proper values are chosen for the stability analysis, a safety factor above 1 would indicate that a slope is stable. Most authorities agree that if a sliding slope has a factor of safety slightly less than $I$ and with a value of .95 or less, rapid failure cas be expected in cohesive soils (HRB Full. 29, 1958). With tinis 


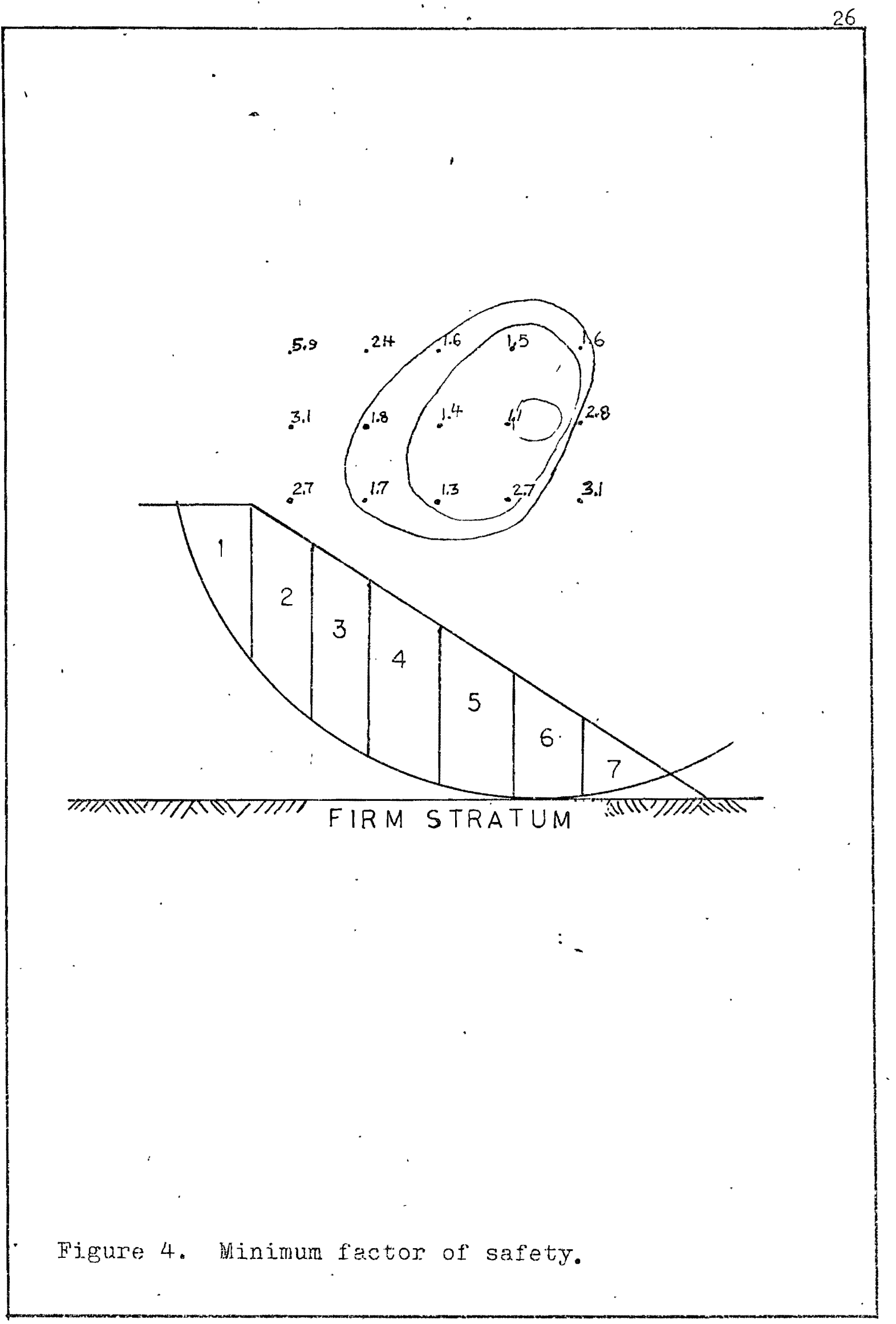


information, it is possible to confirm the stability analysis and choice of soil strength values by reconstructing the original ground surface and finding a factor of safety between 0.95 and I (BRB Bull. 29, 1958).

Uncertainty in dealing with unstable slopes is always present due to inconsistencies in the sliding strata, incomplete data resulting in an erroneous cross-section, presence of unsuspected water and other unknown factors. Correct interpretation of the geological and other test data will reduce the uncertainties in slide analysis to a minimum. 


\section{CHAPTER V}

\section{TREATMENT OF LANDSLIDES}

\section{PRELIMINARY REMIEDIES}

Treatment of landslides is expensive and a poorly planned correction can cause more extensive sliding. Therefore, an understanding of the slide must be obtained before any action is recommended. One of the inmediate treatments used in the Pacific Northwest is tree re"moval. This action has been proven to be detrimental and may actually increase the danger of sliding (Gray, 1970). Earthwork particularly should be avoided until after an investigation has been completed. The Fipe Organ slide, which occurred in 1965 near Dillon, Niontana, is an example where an attempt to correct a small slide by benching and slope flattening resulted in reactivating an enormous ancient slide (Williarns and Armstrong, 1970).

Covering of a small landslide with plastic sheeting is sometimes attempted as a temporary expedient in stabilizing a landsiide (Jeiginton 1966). This should be considered only if the slope is steep enough to afford immediate runoff of rain water. The plastic prevents water from esoaping through evaporation as well as preventing water from entering the soil. If puddles form in depressions on the plastic, water may eventually enter the slide through punctures and increase the moisture problem in the slide. 
When a slide is encountered which is endangering property, the best form of immediate action which can be taken is to reduce the amount of water in the area of the slide mass. This action will seldom cause additional sliding problems on the areas adjoining the slide. There are a number of ways that this may be done. One of the most common is to seal ground cracks to prevent the entrance of surface water. This is done by filling them with compacted earth or by pouring powdered bentonite into the cracks. Bentonite, available for use for driller's mud, is used directly as it comes from the bag (NAVFAC, 1971).

Surface water should not be allowed to stand. Ponds and other enclosed depressions should be drained. Drainage can be accomplished by digging ditches by mechanical equipment, hand tools, or the use of explosives. Jndrained depressions are very common on old slides and may not have free water standing in them. However, any water which enters the depression will eventually soak into the slide.

When treating slides in built up or urban areas, utilities must be considered. Sewer and water lines can be broken by slide movement, allowing water to escape into the slide. A careful examination must be made because both utilities can continue to function even after being broken (Zaruba and Mencl, 1969).

The most important factor to be kept in mind in planning immediate types of remediea is that until a more detailed examination of the slide is made, nothing should be done which could cause trouble Iatex. 
II. PERMANENT TREATMIENT OF SLIDES

Treatment of landslides may be classified into three general categories: (1) avoidance, (2) reducing the driving forces and (3) increasing the shearing resistance.

\section{Avoidance}

The most obvious answer to landslide problems is simply to avoid them. This may be done by recognizing the hazard in the beginning and, with proper land use procedures, avoiding excavation or construction of anything which can be damaged by slide activity. Avoidance does not necessarily mean relocation in the case of a highway or similar structure. Frequently a small change in grade will accomplish the same effect ( $\mathrm{HRB} B \mathrm{Bul}$. 29, 1958). An example is that of the Southern Pacific Railroad which, in 1902, relocated about three miles of track, abandoning several tunnels and a bridge, after a serious sidide Iocated along Cow Creek in Section 12, T32S, R8W, Willamette Meridian.

Another method of avoiding a landslide is to bridge over it. This is frogt commonly done with linear engineering works such as railroads, highways and aqueducts. Bridging is usually done only when the slide itself is narrow with stable sides on which the bridge can be based. Generally a bridge will be more costly than other treatments and it is only used under conditions where other corrective measures are not practical.

A landslide can also be avoided by removing the slide (NAVPAC, 
1971). This is most common when the slide is small. Removal of the slide may also be considered when the value of the endangered work is high or when no failure can be tolerated such as at a dam site with human lives at stake.

\section{Reducing the Driving Forces}

Avoidance methods do not have any effect on the stability of the slide. These methods simply prevent the slide from adversely affecting the engineering work or whatever is in the way. Excavation methods attempt to stabilize the slide by reducing the shearing stresses or by increasing the shearing resistance. It is usually more economical to design slopes which will be stabie rather than to redesign them after sliding has taken place (Zaruba and Mencl, 1969).

Removal of the head of a slike or slope flattening is based on reducing the driving forces on the slide. When designing this type of slide correction, the entire area mast be taken into account and care must be used that the excavation does not remove the support from adjoining areas and cause additional sliding (NAVFAC, 1971).

One of the easiest methods of slide correction is to simply flatten the slope to a safe angle as determined by stability analysis. In fact, there are computer stability programs available which will select the stable slope automatically (State of Calif., 1970). However, there are a number of reasons why this may not be desirable. The topography may be such that slope flattening is impractical doe to the high amount of excavation involved. A large flat slope opens a great unbroken surface to rainfall and serious erosion can result (Iejghton, 1966). 
Benches are usually constructed on slopes which are higher than 20 feet. Hennes, Hawkins and McCoy (1958) found that for a given amount of excavation, slope flattening was less effective in slide stabilization than a slope with benches. Benching has other benefi.. cial effects in that the benches minimize slope wash and, in the case of a nonhomogeneous soil, provide a means for equipment to get up on the slope to clean up small failures and generally maintain the slope. Slope flattening wijl be found to be the most effective on the rotational type of slide and is generally not recommended for the mud flows or slides which have straight slip planes (ARB Broll. 29, 1958). As a rale of thumb, if a slide was caused by excavation at the toe, it will be necessary to remove approximately twice as mach material at the head of the slide to stabilize it ( $\mathrm{HRB}$ Bull. 29, 1958). In many cases, slope flattening with or without benches is used in connection with other slide correction techniques. The excess excavation matexial resulting from slope flattening can result in a serious waste disposal problem. Utilizing the excess to construct a counterbalance at ihe toe of the slide is one excellent solution to the problems of slide stabilization and waste disposal.

Increasing Shearing Resistance

Another means of slide stabilization through excavation methods is the shear key, which consists of a wedge of higher strength soil or rock placed, near the center of the sliding mass. (Figure 6). The shear key extends down through the slip plane into the firm underlying soil or rock (NAVFAC, 1971). The size of the shear key and the type of soils necessary for its construction can be determined through 
ordinary landslide analysis methods. The disadvantages in using a shear key type of slide correction are the difficulty in locating a nearby source of high strength soils and the problems involved in the necessary excavation. The lattex is probably the most serious objection since removing soil to an elevation below the slip plane in the middle of a lendslide can cause further instability problems. Safety is of utmost importance in the design of this type of slide correction. Generally a shear kay slide correction will only be found economically feasible in a rather large slide where the thickness of the sliding mass is thin compared to the length (Leighton, 1966). irainage is particularly effective in slide stabilization as it both increases the shear strength of the soil and reduces the ariving forces acting on the slide. The primary effect of drainage on a slide is the reduction of the pore pressure affecting the slide (Hennes, Hawkins and McCoy, 1958). Water can be removed from tine slide by means of both surface and underground drainage methods. One of the first sieps in the prevention and treatment of slides is to obtain good surface drainage. If possible, all streams and temporary water courses should be diverted from the slide and any standing water, both on the slide and neax it, nust be drained. Sometimes paved ditches and culvext pipes are utilized in order to keep collected water from escaping back into the slide. However, these are subject to rupture if the slide continues to move (Zaxuba and Mencl, 1969). It will usually be found that if the topography lends itself, open ditches are a very effective way of dxainjug the slide. Once water is collected at the surriate and placed in a ditch and kept flowing, the bottom of 
the ditch tends to seal itself with silt and very little water will escape back into the slide. During drainage operations, the existing ground cover should not be disturbed any more than necessary since vegetation removes water from the ground through transpiration of the plants (Gray, 1970).

One of the important features which must be detexmined during the preliminary investigation is the presence of undergronnd water. The drill log should contain the elevation of the top and bottom of the water bearing stratum. Subsurface drainage can consist of both drilled horizontal drains and ordinary drains placed during construction of an embankment. Drains placed under an embankment usually consist of a lajer of free-draining gravel and a series of perforated culvert pipe to allow escape of any water picked up by the gravel. Occasionally a layer of rock is placed under a fill without using any pipe and the water escapes through the voids in the rock (NAVFAC, 1971). This is the so-called "French drain." (Figure 5). This type of drainage is only practical under new construction or in the course of major slide reconstruction.

If the water is encountered in a slide at a shallow depth, a cutoft ảain may be designed (HRB Bull. 29, 1958). (Figure 5). This consists of a deep ditch dug to the botton elevation of the water bearing stratum and across the slide. The cutoff trench will have a perforated pipe placed in it and be partialif filled with free-draining gravel. Ten to fifteen feet is the normal econonio depth of a cutoff drain.

Thuerous methods have been ased to drain landslides if the water 


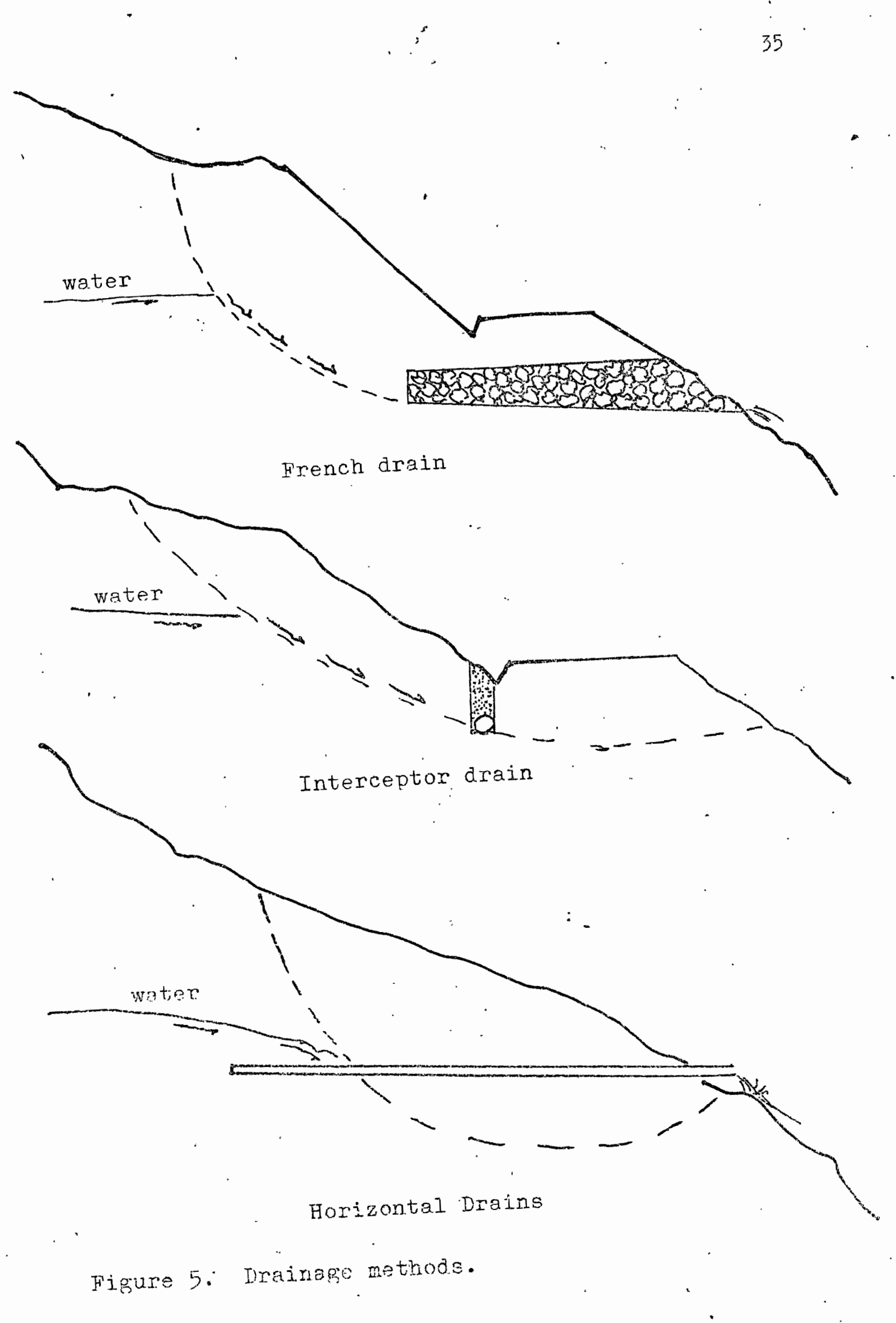


level is too deep to be reached from the surface. Drainage tunnels have been used on some slides in Oregon, but are seldom used today due to high labor costs (Anon, 1947).

Another system of underground drainage which is sometimes used, If the geologic conditions are suitable, is the vertical drainage well. This is used when the water affecting the slide is perched and there is an aquifer below which is capable of accepting water from above (NAVFAC, 197I). When this method is used, care must be taken that the water table in the lower aquifer does not rise during periods of high water, thus introducing water back into the landslide.

Drilled in horizontal drains have supplenented most other means of underground drainage methods in recent years. (Figure 5). This is due to the low cost and the fact that the drain installation causes little dismption to the landscape. In 1974, drilled in horizontal drains cost between $\$ 5.00$ and $\$ 5.50$ per foot, including the pipe. 3 The cost of stabilizing a slide using horizontal dxains usually works out to be 5 to 10 percent of the cost of slide stabilization using other means. Horizontal drains have the advantage that they can be installed very rapidly. A crew of two with a drill designed to install horizontal drains can install approximately 600 feet of drain per 8 hour shict in good drilling conditions. 3 originally the drain pipe was rodisjed water pipe with holes drilled in or burned in with an acetylene torch. Later perforated galvanized pipe became available commercially. At present, nearly all the horizontal drain pipe is constmucted from PV plastic which can be perforated ox slotted. The 
slotted pipe is rapidly becoming the most popalar since the width of the slots are designed to be of optimum size for capillary attraction and also function as a well screen. Horizontal drain pipe is commonly 2 inches in diameter with 3 or 4 inch pipe being used on occasion. Horizontal drains ase generally limited to a depth of 200 to 300 feet. However, they have been drilled as deep as 1500 feet (HRB Bull. 29, 1958). There is no mechanical limit to the depth that drains can be drilled, but after 300 feet one loses a measure of directional controi and the drill will sometimes break out through the surface of the ground, particularly if the material. being drilled is bouldery. This being the case, one can well imagine how many deep holes go astray withou' the operators being aware of the deviations.

Because horizontal drains require a gradient to operate, long drains may be ineffective because of poor directional control. When a slide is so large that long drains are required, such drains are frequently brought to a central spot in the slide, with drainage oxiginating from there. This is usually accomplished by digging an excavation wide and deep enough to lower a drill to the desired elevation. Then a series of drains are drilled out. of this excavation. The State of Washington has drained these excavations by selfstarting siphons or by arilling another drain into the pit (HRB Bull. 29, 3.958$)$.

Horizontal drains are normaily drilled with a gradient of 5 to 25 percent, the angle being determined by the respective elevations of the drill site and the base of the wet stratum. Spacing between dril.Ied in horizontal. drains is sometimes determined by field judgment 
after a fan of drains has been placed across the slide. The drain showing the greatest flow will be bracketed by a drain on either side. The spacing of horizontal drains can also be determined by a rational method once the perneability of the slide is known (Todd, 1959), (Poksoz and Yirkham, 1961).

Because reduction of the pore pressure in the slide has a great stabilizing influence on a slide, observation wells or piezometers should be installed in the preliminary exploration holes. The effect of the drain system can then be evaluated as the drains are installed. This evaluation is particularly important since it is possible to get a reasonable flow of water from a drain installation and yet find that the hydrostatic head has not been lowered (HRB Bnll. 29, 1958). Occasionally a small flow will prove effective in reducing the inead in the slide, but if the installation were evaluated on the basis of the flow, it would be judged a failure. Observation wells also allow the continued monitoring of the slide since drains require periodic maintenance. A program of checking observation wells can provide advance warming that whatever stabilization technique was used may be in imminent danger of failing.

Restratning structures can be constructed of materials other than rock ox earth, but these are exceptions used infrequently due to the size of the forces involved in landslides. Piling, cribs, dowels, rock bolts and tie roris have all been used as rastiaints (HRB Bull. 29, 1958).

Slides which are predominately in hard bedrock and are moving along fractures have been successfully restrained by rock bolts. Rock 
bolts are a special case and do not depend directly on the shear strength of the steel for their restraining effect but on the friction generated as the rock is forced together under compression. The design of successful slide correction, using rock bolts, requires considerable exploration. Since the rock bolts work by pulling the rock into compression, the minimum depth to which the rock bolt must be anchored is critical (NAVFAC, 1971).

A notable case where piling have been used successfully to restrain landslides is in Seattle, Washington along Interstate Highwey 5. Here a number of large slides were restrained by a combination of drainage and large cast-in-place cylinder piles. (Figore 6). Correction by the use of piling is not always successful as the forces involved are too great to be arrested by piles, or the sliding material will flow through the intervals between the piles. Piling, if unsuccessful, can have a negative effect on the slide if they are moved by the action of the slide. The material into which they have been driven will be disturbed and the slide can deepen. As a general rule, for pilings to be successful they must penetrate $1 / 4$ to $1 / 3$ of their length into stable material and there should be at least one pile for erery 50 cubic yards of moving mass ( $\operatorname{IRB}$ Bull. 29, 1958). Cribs, retaining walle and bultheads are most likely to be effective if installed before sliding occurs (HRB Bull. 29, 1958). Once a landslide moves, it disrupls the soil and some of the strength of the soil mass is lost because the remolded gtrength of a clay is lesa than the oxiginal strength (Irambe and Whitman, 1969). These structares sust resiat both the shearing action of the slide and the overtuming 


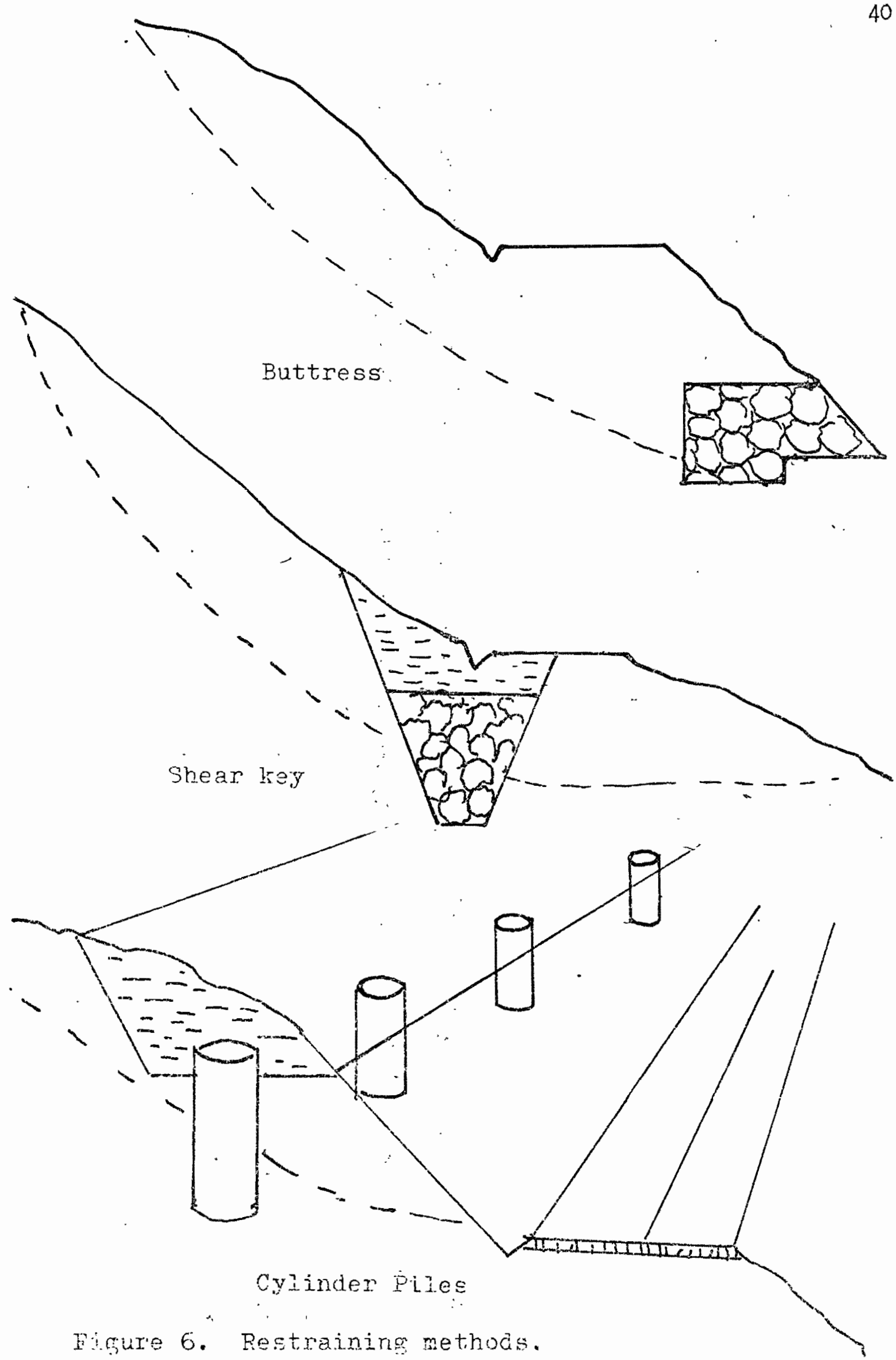


action. The most critical factor in designing this type of landslide correction is to provide for drainage through the structure.

Buttresses are probably the most common restraining structure which are designed to correct slides. (Figure 6). These axe constructed at the toe of the slide and are usually made of earth or rock. Buttresses and counterbalances are usually constructed of a material stronger than the wative soil. This is not necessary in the cass of the counteribalance design where only the mass of the material is utilized. Counterbalances are constructed at the toe of a slide where the slide material forms an upward bulge. The design is critical in that if weak material from the slide is used to construct the counterbalancs, it must guard against the instability of the counterbalance itself. A combination of slope rlattening and buttressing is often found to be a most effective means of slide correction (NAVFAC, 1971). The design of restraining structures follows the normal soil mecharics method of slide analysis. There are computer programs availatle which will automatically analyze the slide and construct the counterbalance to a preselected factor (State of Calif., 1970). Caution must be used here because the counterbalance can automatical.J.y be constructed hi.gh enough to have lateral failures. Generally, a stability analysis is made on the center of the slide so when designing a buttress, it is advisable to check a section on either side of the center as well. In adition, one should be sure that the slopes used in the buttress or counterbalance will be stable. A second situation which comaoniy ocours when a counterbalance is used is that there wiIl be thu critical. failure arcs。 one will be a large radius deep arc 
which will involve the whole slide and counterbalance. \& second will be less deep, cutting the surface of the ground just above the buttress or counterbalance (Zaruba and Mencl, 1969).

There have been two general methods used to stabilize landslides by hardening the soils - chemical and electrical.

Chemical methods generaily consist of the addition of a chemical such as lime, calcium, chloride or phosphoric acid. These will react with the clay minerals present in the soil, changing them to a less sensitive clay or reducing their affinity for water (NAVFAC, 1971). This technique has been used by the Oklahoma Highway Department on several locations. ${ }^{4}$ Briefly, their techmique is to make borings to the depth of the slip surface at an approximate spacing of 10 feet. These borings are then filled with lime. They feel that for this method to be effective, the slide must be made up of $A-6$ to A-7 soils with the moisture content slightly above optimum. Evaluation of the slides treated in this manner indicates that the major effect has been water removal and lowering or the optimm moisture of these soils rather than increasing the strength of the soils.

A recently developed proprietary process. also stabilizes slides using chemical means. 5 The method is based on the introduction of one or nore chemicals which react with the existing soil minexals causing a permanent chenge. The actual chemicals used are a trade secret and are selected on the basis of Iaboratory teste. This method does not

\footnotetext{
4personal commuication, Charles $\Gamma$. Robertson, Materials Engineer, oklahorna Highway Departinent.

5ron Pech, Jac. 1680 Bryant Street, Daly City, California
} 
require that the slide be primarily clay, and it can be composed of a large percentage of silt. It does require that the existing slide have a safety factor of approximately 0.95 .

The chenical processes are relatively inexpensive compared to other methods of landslide correction.

Another method of hardening soils is the electrical method. Blectrical pressure can be used to remove vater from the earth - a process defined by the term electro-osmosis. This has been applied to horizontal arains to make them function more effectively. Casagrande (1953) recomnends the use of electricity for simultaneous soil hardening and water removal and holds U. S. patents on the process. The principle is that the water well or horizontal drain pipe acts as the cathode. The anode is usually aluminum. The electrical current ionizes the aluminum which then exchanges with sodium or calcium ions in the clay causing a permanent change in the clay.

The Casagrande method was used in King County, Washington to stabilize a sliding condition on the east end of the Evergreen Point Floating Bridge across Lake Washington in 1962.6 Power was furnished. bJ two l.OKW welding generators with 140 cathodes and 70 aluminum anodes. The dewater hardening processes operated 24 hours a day for gix days. 20 to 25 gallona of water were removed per day from each cathode and a solidified colun 16 feet in diameter was formed around eacis anode.

A number of other methods of slide stabilization have been tried at various times. The only two which are in use at present are

6ecorde, Tederal Highway Aỏministration, olympia, Washingtos 
blasting and rock blankets. Blasting is seldom used today. The method consists of increasing the shear resistance by disrupting the slip plane and fracturing the sliding surface to allow water to escape (Zaruba and Mencl, 1969).

Rock blankets are used extensively on small mudfiow slides in the Pacific Northwest with considerable success. The principle of the method is to place a covering of free draining material on the unstable slope. Either rock or gravel may be used, although tradition favors large shot rock. The rock blanket, usually 3 to 5 feet thick, is placed on the slope of a mudflow type slide. This porous material allows the water to escape while restraining the soil. Rock blankets are designed on the basis of practical experience (NAVFAC, 1971 ). 
CHAPTER VI

CIACKAMLAS ILANDSLIDE

I. INIRODUCTION

The following is an example of analysis and treatment of a Pacific Northwest landslide. This slide is located about 30 miles east of Portland, Oregon along the Clackamas River in the NEs Sec。19, T4S, R6E, Willamette Meridian. Excavation of a cut during reconstruction of the Clackamas Highway in 1968 triggered a slope failure which blocked the highway and endangered a key utility tower. whe initial f'ailure took place zapidly, during a period of heavy rainfall, and was witnessed by a construction worker. According to this witness, a. large mass of earth about 15 feet high moved rapialy across the highway. The majority of this material disappeared into the adjoinirg river. Arter this slide movement was over, the only visible evicuence rerotining was the 3 to 6 feet of debris on the road, the scar on the s]ope and some muddy brush caught on the telephone line located between the road and the river.

Because this slide posed a serious threat to the high roltage transmission tower as welz as to the highway, an extensive exploretior and analysis program was undertaken on this slide by the Federal Highway Administiation. 


\section{BACKGROUND}

The preparation of a contract to reconstruct portions of the Clackamas Highway, Suate Highway 224, were nearly complete in December 1964 when the road suffered serious damage due to flooding. Arter emergency repairs were completed to make the highway passable to traffic, intensive redesign work was undertaken to add the flood damage repair to the reconstruction contract. The federal funds arailable for flood damage repair had to be expended in a limited time making rapid completion of the redesign work imperative. As a result of the need for haste, a very limited soils survey was done on the flood danaged areas and this slide was not identified during the design stage.

The terrain in the vicinity of the slide is comprised of nearly vertical basalt cliffs between moderately rolling uplands and the Clackamas River. Bedrock, where exposed is mapped as Boring agerioo merates (Baldwin, 1964).

The nearest J. S. Department of Commerce Weather Bureau Station is at the Three Iynx Ranger Station. Using data available from tisis station, the slide vicinity is found to have average annual precipitation of 65.5 inches including a mean annual snowfall of 34 inches. The mean temperature is $51 \mathrm{~F}$, but extremes may range from $105 \mathrm{~F}$ to a low of minus 4 F.

The original back slope was designed on a $.75: 1$ which proved too steep for stability. In acidion to the large Pailure described earlier, a series of swaller failures took place during construction. 
As' the project was under construction, it was decided that a delay for investigation of the slide could not be tolerated. It was arbitrarily decided to correct the slide by flattening the slope to 1.5:1. This did not prove effective and additional small failures occurred during the remainder of 1969.

It was then decided that a complete investigation shoujd be made of the slide. This decision was made primaxily because Portland General Electric's higin voltage transmission tower 97 appeared to be in danger if sliding continued. This tower is especially critical as it is the highest in a series of towers. If it should prove necessary to move tower 97 , as marly as 10 other towers could require movement or modifications.

\section{EXPLORATION}

In order to accomplish the field exploration in the most efficieat manner, aerial photographs, plans, cross-sections and soils survey data were reviewed. The aerial photographs revealed that the slide was only a part of more extensive sliding which extended to the easit and west along the Clackamas River. A large slide scar was found just west of the sidae under study. (Figure 7).

The detailed field investigation took place during December 1969. A prograu of mapping, dxilling sampling, geophysical (seismic) testing and ins immentation was implemented. (Plate 2). A truck-mounted Acker core arill was used with both auger and regular drilling equipment to mike the exploratory boxings and obtair the desired samples. A total of ax borings were made in the slide area. Because the slide 

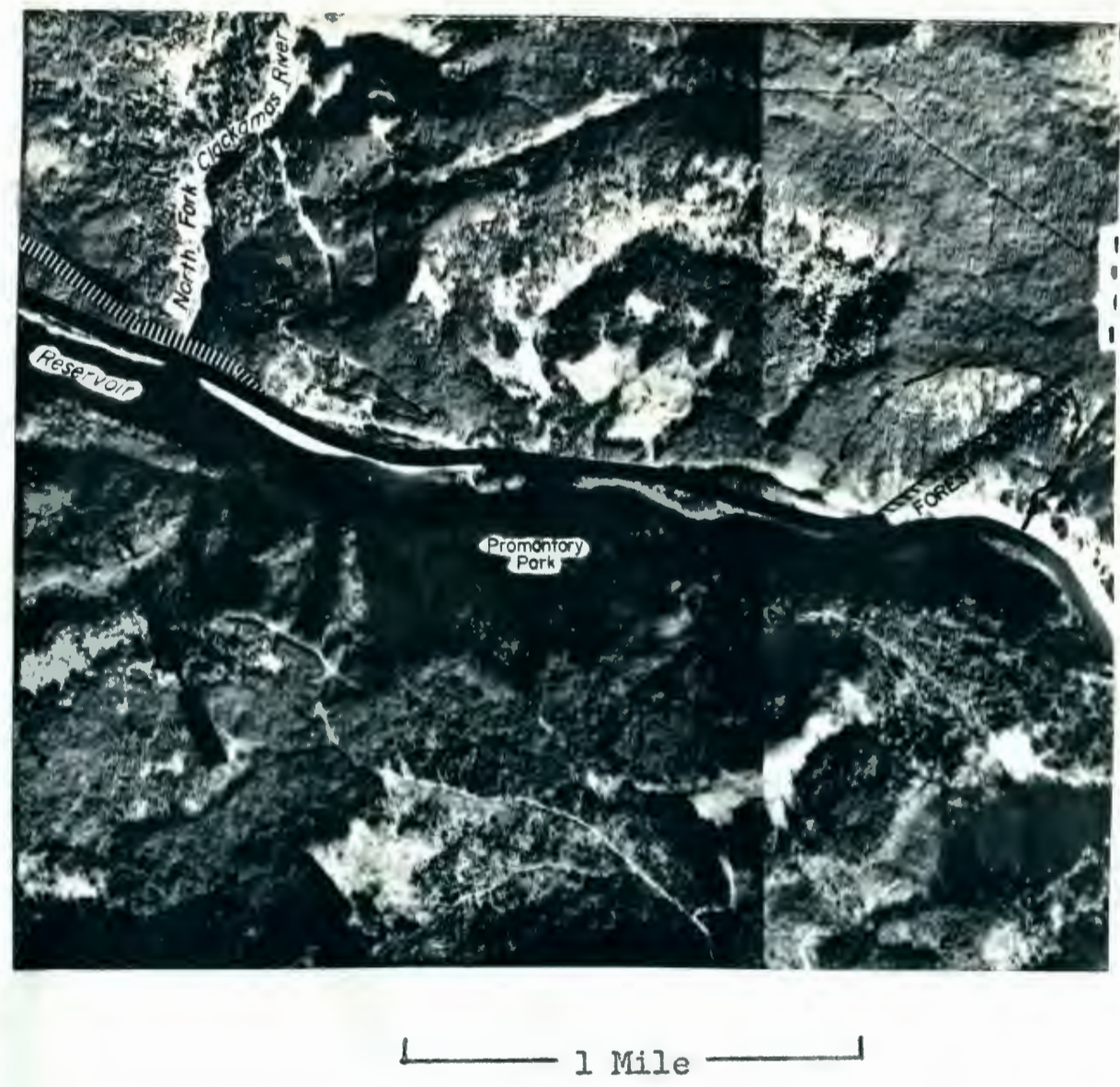

Figure 7. Station 425 Clackamas Highway silics. 
activity had been related to periods of heavy rainfall, as much of the boring as possible was accomplished using augers which do not introduce water into the gronnd while driliing. Augexing was mase difficult by the presence of boulders in the slide material. Only one of the six borings was completed using augers alone. The othexs were augered to refusal and the boring completed using a 3-3/4 inch tricore rock bit. Fine water table was measured immediately in the avgered. hole and again after a several day period to allow water to reach equilibrium in the rock bitted holes. In order to provide for future water table measurenents, one inch electrical conduit was placed in five of the six holes for use as observation wells. Since the safety of the Portland General Electicic transtaissjoa tower was of gwjoury considexation during this investigation, an incinoneter twise was placed in boring number 3 near the tower.

Wampling of the different soil strata vas done by mears of a shelby tube sampler and a stationery piston tube sampler. Augex cuttines were also collected and sealed in glass jars, Samples of the vpex slide debris were collected with little difficulty, but considerable difficulty was experienced in sampling the wet soil asspciated with the slip plane. Whe difficulty was pximarily that the layer was thin and underlain by a harder stratum which shelby tubes cowld not penetrate. In several cases the layer was not detected until after the layer had been completely penetrated. This was especially trae when the cock bit; was bejng used. Whe ase of water when rock bithing though large boulders softened the soil, making it impossible to ajstinguish between the naturaliy oceurring bard and soft iayerg. 
Water introduced during drilling also made it difficult to identify the water bearing strata, if present.

Five refraction seismic lines were run on this slide using an Electro-Tech PRA-2 12 charneI seismograph. The lines were tied to the borings in an attempt to expand the information economically on the slip plane obtained in the borings. Iine 5 was man halfway up the slope providing slip plane data in a location where the information was extremely useful and woula have been difficult to obtain by other means.

The Electro-Tech instrument provided a permanent record, although the Kodak 1875 self-developing paper which was used resulted in a record unsuitable for reproduction. The data was reduced using an IBY 360 electromic computer with the resulting interpretation spotchecked by hand calculations. Each seismic line was shot in the center of the line in additicn to the two ends in order to increase the number of end-point determinations. The seismic data showed a three layer condition with 1500 FPS and 3500 FPS layers above the slip plane and 6000 FPS in the firmer material below. (Plate 3)

The field investigation revealed that the moving slide material consisted of soil boulder slide debris. This material was sliding on a thin layer of reddish brown medium plastic moist clay. The material under the slip plane was a firm weathered rock which in turn overlay a harder rock. One of tive shelby tube samples contained a six inch layex of very porous volcanic tephra recovered from a layer just above the weathared rock layer. There may be a discontinuous layer of this porone reterial in the siide which is conveying large amounts of water 
to the slip plane.

\section{LABOKATORY TESTING}

The laboratory testing consisted of routine identification and one unconfined compression test. (Table I). The number of laboratory tests was severely limited because of the poor sample recovery in the field. Some unaisturbed samples recovered in shelby tubes contained trapped water. The samples flowed out of the tube when opened in the laboratory so that valid tests could not be performed on this material.

The Atterberg limits, moisture content and grain size distribution wexe used to estimate the strength of the cohesive material.

\section{STABILITY ANAIYSIS}

The laxaislide at station 425 appears to have had two and possibly more active stages in its history. The exploration indicates a nearly flat surface associated with the top of the weathered rock. The current movement is largely rotational with some mudflows taking place near the toe. Because of this, two methods of stability analysis were used in analyzing this slide.

Wedge analysis (Figure 8) was used to analyze the sliding type of feilure associated with the earlier sliding movement. The wedge analysis shows a faction of safety well above unity, tending to corfins the field cbservaiions that the current sliding is of a rotational nature. These resuits muet be applied with some caution since the soil strength data on which the calculations are based was limited due to the poos sample recovery at the slide. It is probable that tine 
TABT_E I

LABORATORY DATA CLACKAMAS LANDSIIDE

Boring No. 1, Location Station $324+50,240^{\circ}$ Lt. $\notin$

Sample No.

Depth

Sieve Size

Percent Passing

No. 4

No. 10

No. 40

No. 200

$0.02 \mathrm{IM}$

$0.005 \mathrm{MM}$

Natural Moisture

Specific Gravity

Iiquid Iimit

Plasticity Index

Shearing Stress
1

$20 \mathrm{Ft}$.

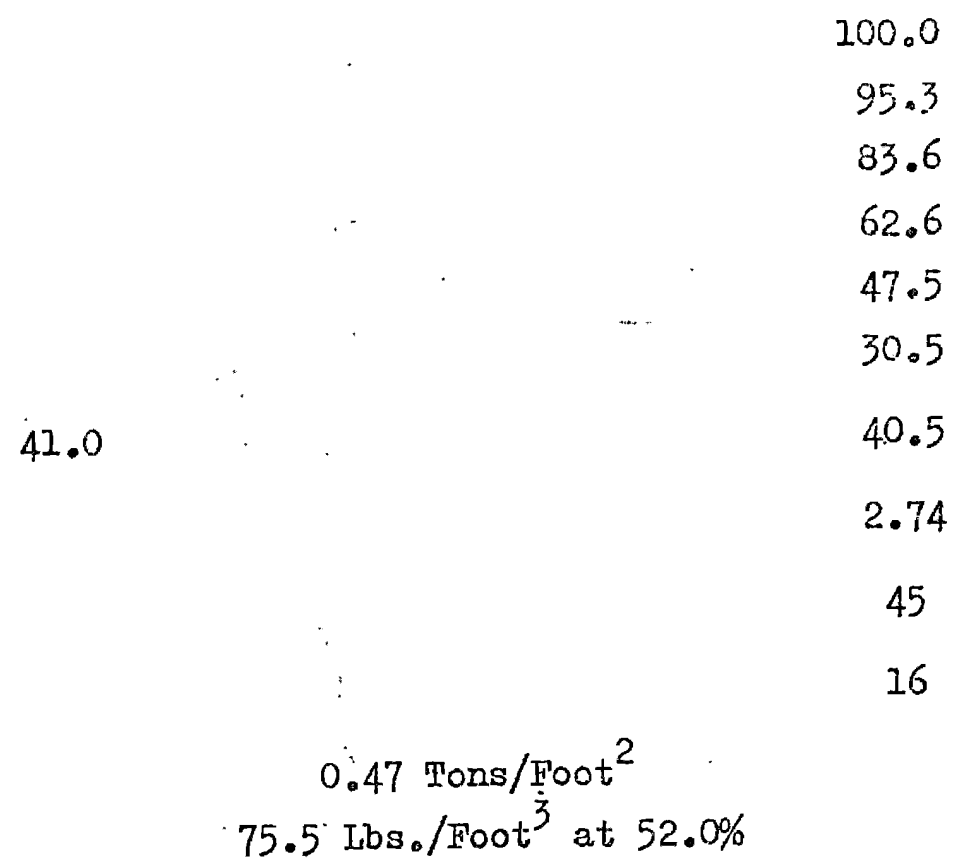




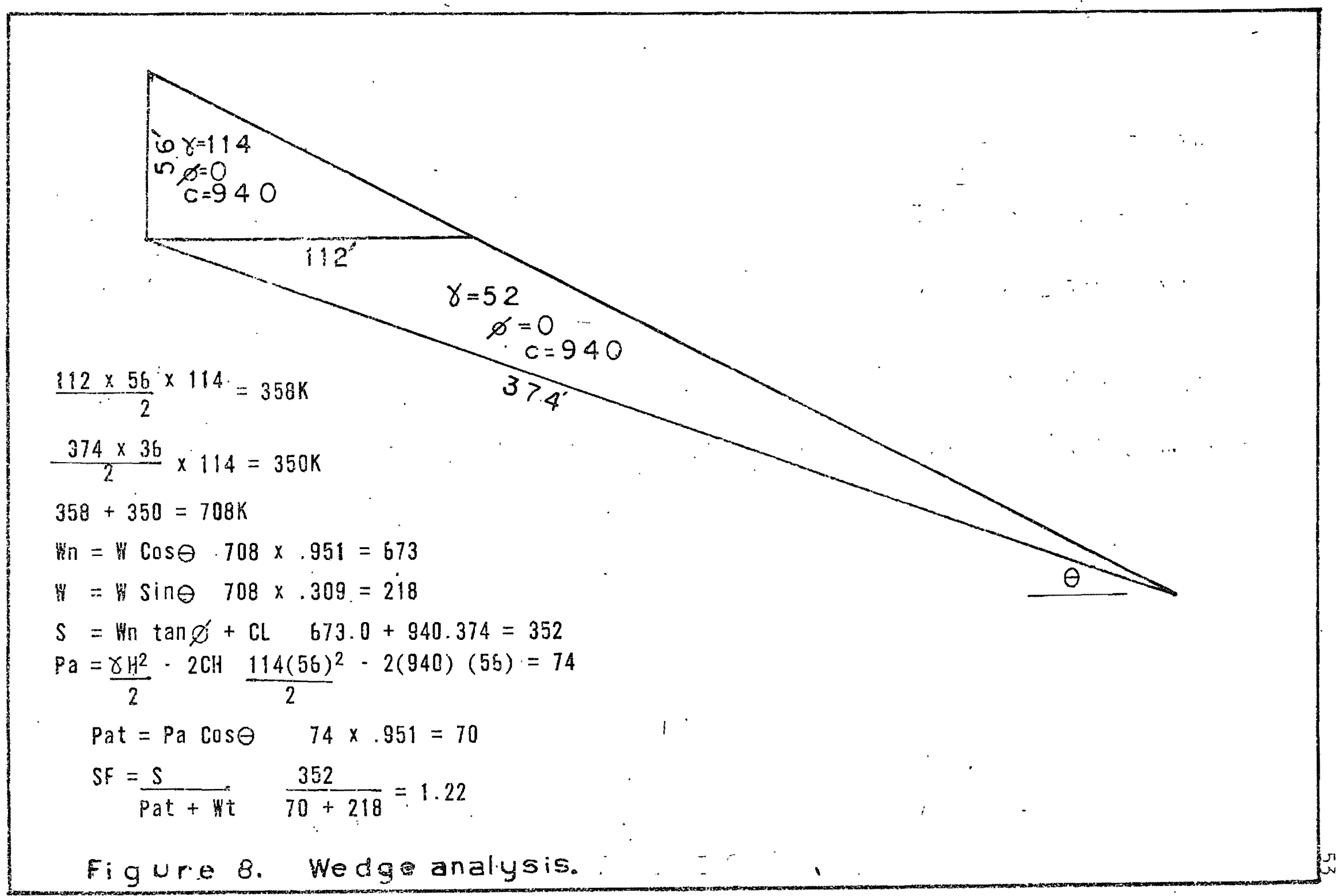


natural slope was close to equilibrium having been formed by sliding originally. This fact was utilized to confirm the soil strength values used by performing an analysis using the original slope and finding a safety factor of 1 .

The slide was also analyzed using both the ordinary method of slices and the modified Bishop method on an IBM 360 electronic computer. These results show a factor of safety of less thail 1 for a failure arc just touching the top of the veathered layer. ritgrese shows an example of one of the computer analysis.

A number of analysis, both wedge and circular, were prepared designing a buttress to correct this slide. It was found that the most economical buttress which could be designed would consist of rock having weight of 140 poundis per cubic foot and an angle of internal. friction of 40 , and in the shape of a parallelogram 40 feet thick and 30 feet high. Analysis also showed that a reduction of the water table would have a stabilizing effect on the slide.

\section{VI, CORRECTION}

The stability analysis indicated that the head of the slide had only maxginel stability and that aditional slope flattening would not be advisable. An acceptable factor of safety could be obtained by constructing the rock buttress previously described, but it would be an extromely costly solution due to the size and the need for the construs:tion at the base to be about 10 feet above the hgihway grade. The excavation necessary at the toe of the slide would also involve some misk failure during constraction before the buttress was in place. 


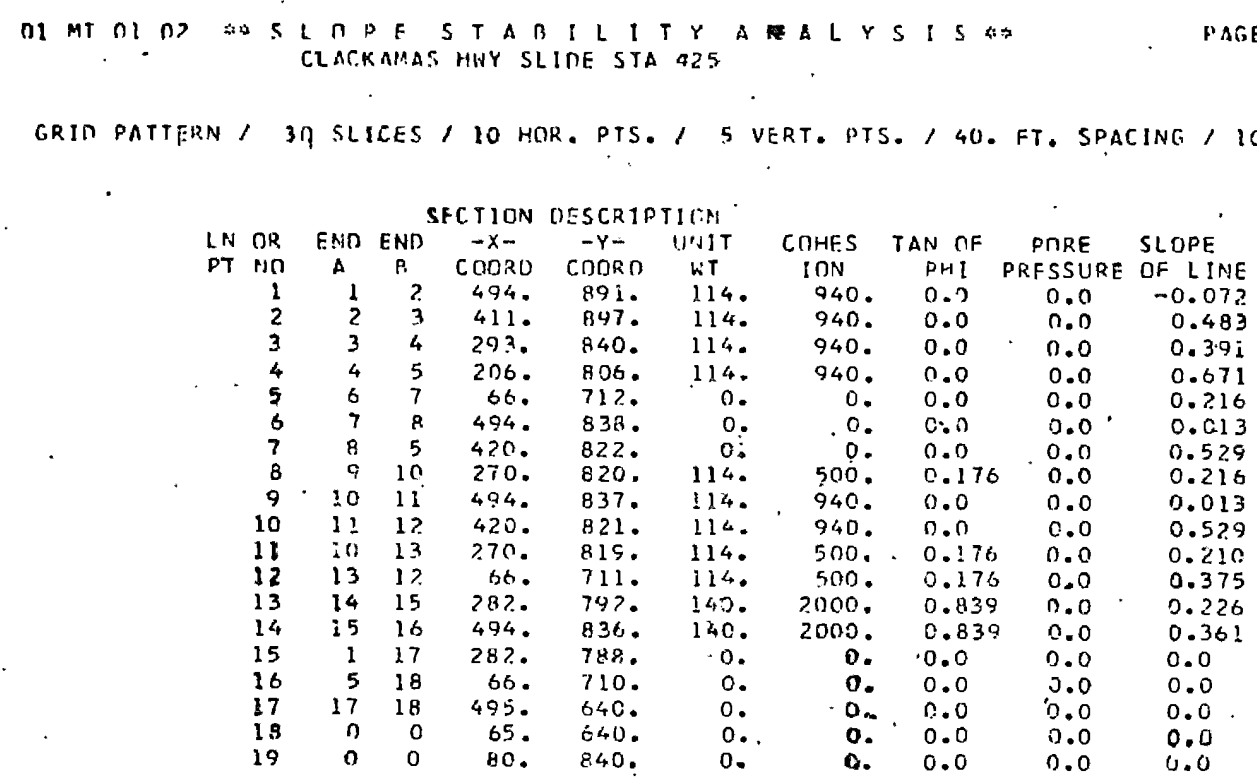

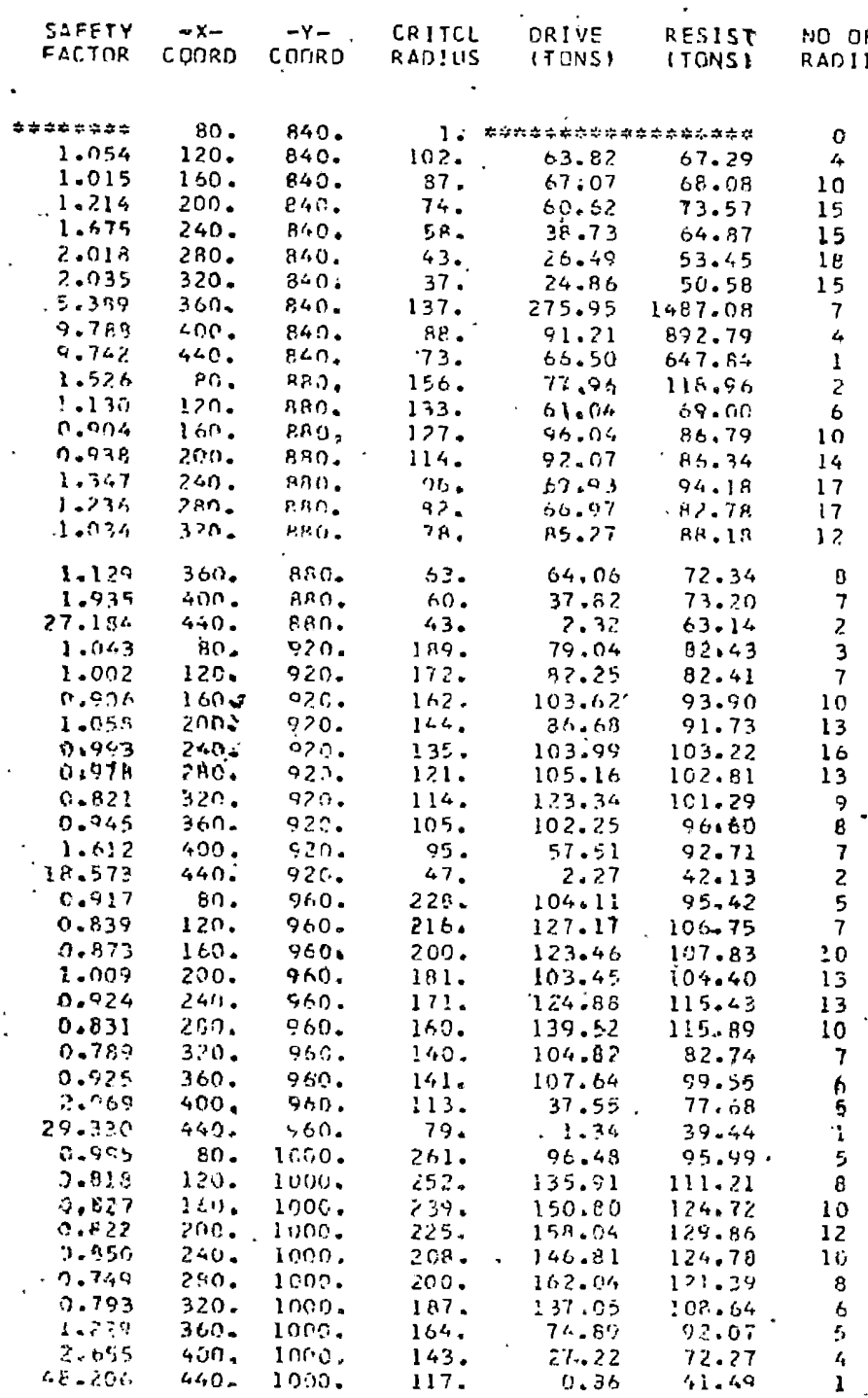

Figure 9. Computer analysis Clackanas Highway. 
For these reasons, correction using a rock buttress was abandoned in favor of other corrective measures.

Reduction of the water pore pressure had also been shown by stability analysis to be effective in stabilizing the slide. A systern of drainage utilizing both surface ditches and horizontal drains was proposed as the most economical method of comecting the slide. Watex entered the auger holes rapidiy during the exploratory drilling indicating that drains should be effective since the formation was reasonably permeable and water was present.

Approval was obtained for an attempt to correct this slide by drainage. A drainage ditch was surveyed and staked out to drain the swamp shown on Plate 2. Permission could not be obtained to do the necessary dozer work to dig the drainage ditch or to site the drill for installing horizontal drains in the most favorable location. Permission was obtained to install the drains if the existing cut slope was not disturbed and a less desirable drain site was selected at a higher position on the slide.

In March 1972 fifteen drilled in horizontal drains and three additional exploratory borings numbered 7,8 and 9 were installed in the silde. The drains were planned as a first step in stabilizing 。 the slide to see if they would be effective in reducing the water levels in the slide.

The results do not appear to be completely successful since, although the drains are working and won vaxying amounts of water from o durine the dry summex up to 4 gallons per minute measured in the winter, the vater table as measured in the test borings still remains 
at approximately the same elevations as before the installation of the drains. The fact that the drains were not successful was proven when an additional failure occurred in January 1974 after a period of heavy rains. This most recent activity occurred along the scarp previously formed and shown on the map. (Plate 2). Movement along this scarp is estimated to be about one foot. About 500 cubic yards of debris was deposited on the road in the spring of 1974.

\section{CONCIUSIONS}

This slide was not recognized before constmuction started due to the lack of time for a normal soils investigation. Had this not been a rush project to repair the flood damage, the slide would undoubtedly have been identiried with the use of aerial photographs and the other techniques described earlier as part of the nomal soils survey. The topography in the slide area and the design requirements for grade plus the alignment of the highway would have made it impossible to avoid the slide in any event. It certainly would have proven more economical to include the slope flattening in the original contract, had. the slide been recognized, than doing it later by change order duxirig construction as was done.

Corrective measures wexe taken in the field before any exploration was accomplished on the slide which is risking the possibility of making a back situation worse. In this case, the subsequent investigation showed that slope flattering did contribute to the stability of the stide.

The iaformation gathered indicates that this slide is a reacti- 
vation of a small portion of a large ancient slide caused by steepening a slope in the process of road construction. The original slide appeared to be a block glide. The current novement is rotationa] with some mudflow activity occurring at the toe.

The inclinometer instalied near tower 97 shows that movement has not taken place since its installation on January 5, 1970 to the most recent reading on March $15,1974$.

The horizontal drain installation, while removing water from the slide, was not successful in lowering the water table in the slide vicinity.

Recommended future corrective measures include flattening the slope to a minimur of 2 to 1 and the addition of a rock blanket to prevent mudflows. Additional drilled in drains should be installed lower on the slope as a further effort to lower the water lovel in the slide.

Careful monitoring of all the instmumentation will be needed for several rears to provide a waming should the head of the slide expand. and endanger the power line tower. 


\section{BIBLIOGRAPHY}

Anonymous (1947) Curing Slides with Drainage Tunnels: Roads and Streets, vol. 90, no. 4, pp. 72-76.

Baldwin, F. M。 (1964) Geology of Oregon, University of Oregon Cooperative Book Store, Bugene, Oregon.

Bishop, A. W. (1955) The Use of the Slip Circle in the Stability Analysis of Earth Slopes: Geotechnique, vol. 5, pp. 7-17.

Bishop, $A_{*} W_{0}$ and Henkel, D. Jo (1964) The Measurenent of Soil Properties in the Triaxial Test, Edward Arnold Publishers, Ita., Iondon.

Capper and Cassie (1949) The Mechanics of Engineering Soils, MoGrawHill Co., Inc., New York.

Carlsor, C. E. and Hoffuan, W. F. (1969) Stability Analysis of Slopes and Irabankment Foundations, BPR Program No. S-3, J. S. Dept。 of' Transportation, FederaI Highway Administration, Washington, D. C.

Casagrande, I. (1953) Review of Post and Current Work on Electrom Osmotic Stabilization of Soils; Harvard Soil Mechanics Series No. 45, Cambridge, Mass. (Reprinted Nov. 1959 with supplement).

Crandell, Dwight R。 (1971) Postglacial Lahars from Mount Rainier Volcano, Washington, U. S. Geological Survey Professional Paper 677,75 pages.

Departnent of the Navy (1962) Design Manual, Soil Mechanics Foundam tions and Earth Structures, Nav. Docks DMar7, Dept. of the Navy Bureau of Yards and Dock, Washington, D. $\mathrm{C}$.

Departnent of the Navy (1971) Soil Mechanic Foundations and Eerth Structures, NAVFAC DM-7, Superintendent of Documents, Washington, D. C.

Dunnicliffo C. J. (1971) Rquipnent for Field Deformation Measurenents: Frocesdings of the Fourth Panamerican Conference on Soil Mechan-. ics and Founàatiun Fngineering, San Juan, Puerto Rico, pp. 89103

Fellenius, N. (1927) Erdstatische Berechnungen Mit Reibring urd Kohasion und uxtex Anrahne Kreiszylindrishex Glextflachen, Ermst $t$. Sohn, Berlin, 40 pages. 
Gray, Donald H. (1970) Effects of Forest Clearcutting on the Stability of Natural Siopes: Bull. Assoc. of Eng. Geol., vol. VII, no. 1 . and 2, pp. 45-66.

Eenries, R. G., Hawkins, S. E. and McCoy, E. I. (1958) An Appraisal of Measures for Improvement of Slope Stability: Highway Research Board Bull. 216; Washington, D. C., PP. 17-30.

Highway Research Board (1958). Landslide and Fugineering Practice, Special Report No. 29, Washington, D. C.

Fighway Research Board (1959). Landslide Occurrence and Analysis: Bul1. 216, Washington, D. C.

Janba, Nilmar (1954) Stability Analysis of Slopes with Dimensionlesa Parameters, Haurard Soil Mechanics Series, No. 46, Cambridge, Mass.

Jones, Valter V. and Peebles, J.J. (1966) A Study of Groundwater Movement in Landslides, Mniversity of Idaho Ing. Kxperiment Station, Moscow Idaho, 160 pages.

Iadd, G. F. (1935) Iandslide; Subsidences and Rockfalls as Problems for the Rajlroad Engineer: Am. Ry. Fng. Assoc. Proc., vol. 36, pp. 1091-1162.

Lambe and Witiman (1969) Soji Mechanics, John Wiley and Sons, Inc., lew Yonk.

Leightor, F. B. (1956) Lamaslides and Hillside Development: Fngiw neexidg Geology in Southern Calif., Assn. of Engineering Gaologists, Arceilia, Calif., pp. 149-193.

Moore, R. W. (1955) Geophysics, A Diamond in the Rough: Proc. 3rd Innual Shg. Geol. and Sojls Symp., Boise, Idaho, pp. 41-64.

Morgeneiein, N. R. and Price, V. E. (1965) The Analysis of the Stability of General SIip Surfaces: Geotechnique, vol. 15, gp. $79 \times 93$.

Schlickex, H. G. (1956) Iandslides: Ore Bin, vol. 18, no, 5, pp. 39.. 43.

Schuster, Kobert I. (1967) Selection of Shear Sticngth Parameters fox Slope Stability Mralysis: Proc. 5th Annual Finst Geol. and Soils Symp., Pocatelio, Idaho, pp. 33-46.

Sharpe, Ca Fs. (1938) Landsilides and Related Phenomena, Colurabia Unitrexsity Press, New York. 
Singh, Aytar and Iee, K. I, (1970) Variability in Soil Parameters: Proc. Eth Anmual Bng. Geol, and Soils Symp., Pocatello, Idaho, pr. $259-184$.

Skempton, A. Wo (1948) The liate of Softening of Stiff Fissured Clays: 2nil Inter. Conierence on Soil Mechanics and Foundations, fingineer. Pr., Rotterdam, voI. II, pp. 50-53.

State of Calif. (1970) ENG-004 Slope Stability Computation, Computer Systems Dept.s Division of Admin. Serv., Dept. of Public Works.

Stout, fartin I. (1971) SIip Surface Geometry in Iandslides, Southem California and lorway: Bull, of Assoc. of Eng. Geol., vol. VIII, no. 1, pp. 59-79.

Taylor, F. W. (1937) Stability of Earth Slopes: Journal Boston Soc. af Civil Engres., vol. 24, no. 3 .

Terzaghy, Karl (1936) Stability of Slopes of Natural Clay: 1st Inter. Conference on Soil Mechanics and Foundation Eng., vol. I, ppe $161-165$.

Texzaghi, Iarl (1950) Mechanism of Lendslides, Application of Geology to Ingireering Practice: Berkey Volum, Ceol. Soc, Am, pp. $23=123$.

Todd, Darid Ko (1959) Groundwater Hydrology, John Wiley and Sons, Janc.s New Yomk.

Toksoz, Sadik and Kirkham, D. (1961) Graphical Solution and Interpretation of a New Irain Spacing Formula: Joumal of Geophysical Research, wol. 66, rio. 2, pD. 509-516.

J. S. Deprertment of Commerce, Burean of Public Roads (1961) Landslide Inyestigations, J. S. Governent Prining Office, Washington, D.C.

Waskburm, A. I. (1967) Instrumental Observatious of Mass Wasting in the Mesters $\mathrm{Vig}$ District of Northeast Greenjand: Meddeleliser Om Grovland Jdgivne Af Kommission for Videnslagelige, Undersogelser I. Grontand, bd. 166, ne. 4 .

Willians, J. A. and Arnstrong, J. E. (1970) lurestigation of a Iarge Jexadslide Astoeiated with Construction of I-.I5 near Dilion, Montana: Pros. 8th Amual Fing, Geol, and Soj.ls Symp.s Pocatello, Idakio, pp. 91-108.

Wilson, S. D. (1969) Observational Data on Ground Movements Related to Slope instability: Joumal. Soil Mech. and Found Div, Froo. Axp. Soc, of Cir. Engo, pp. 1519in.L544.

Remibe, a. and Meacl, $\nabla$. (1969) Jandslides and their Control, Fisew Vier Erb., New Yorir. 


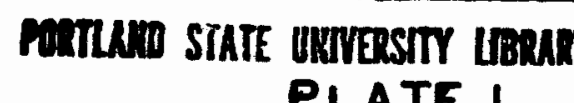

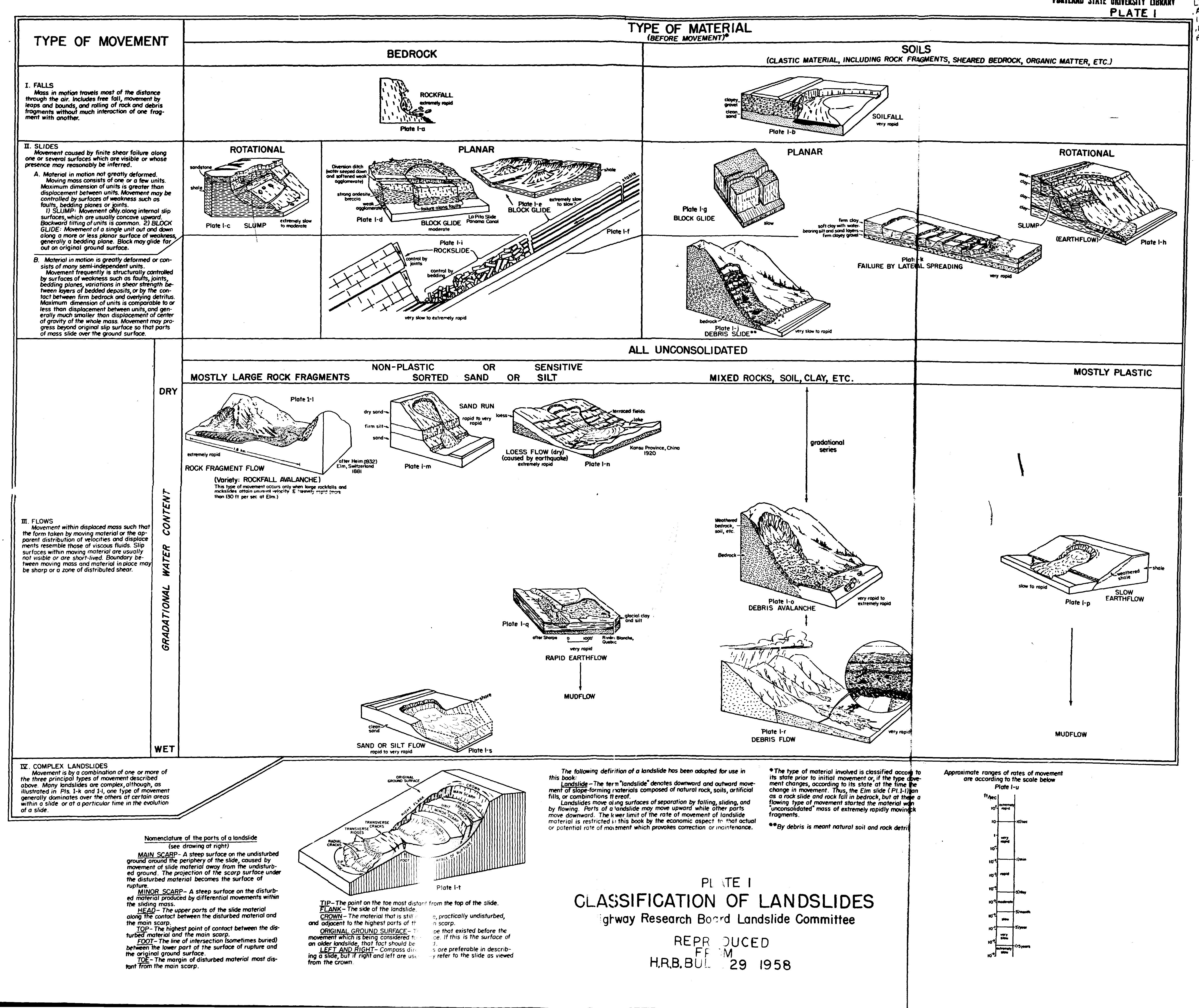




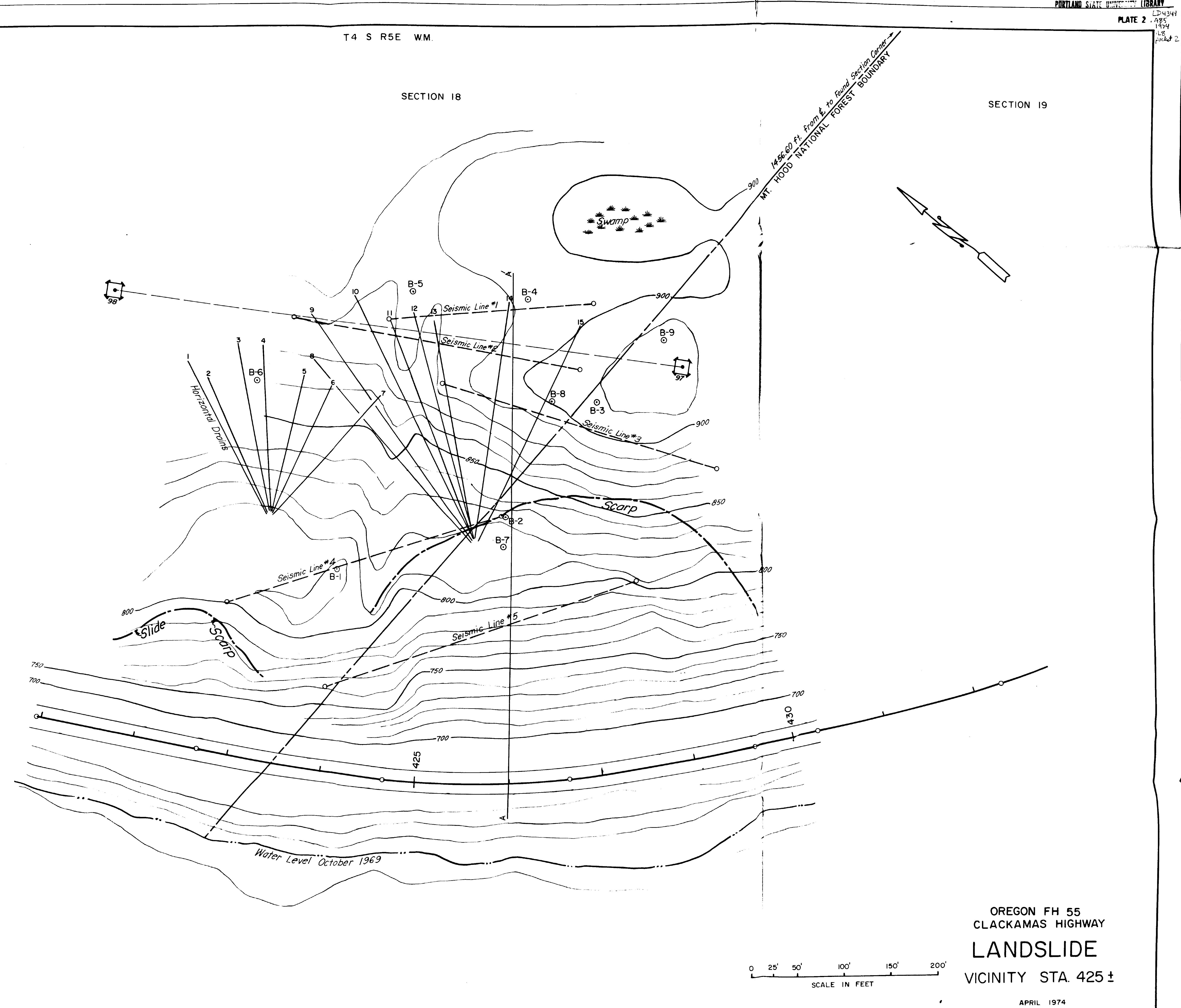




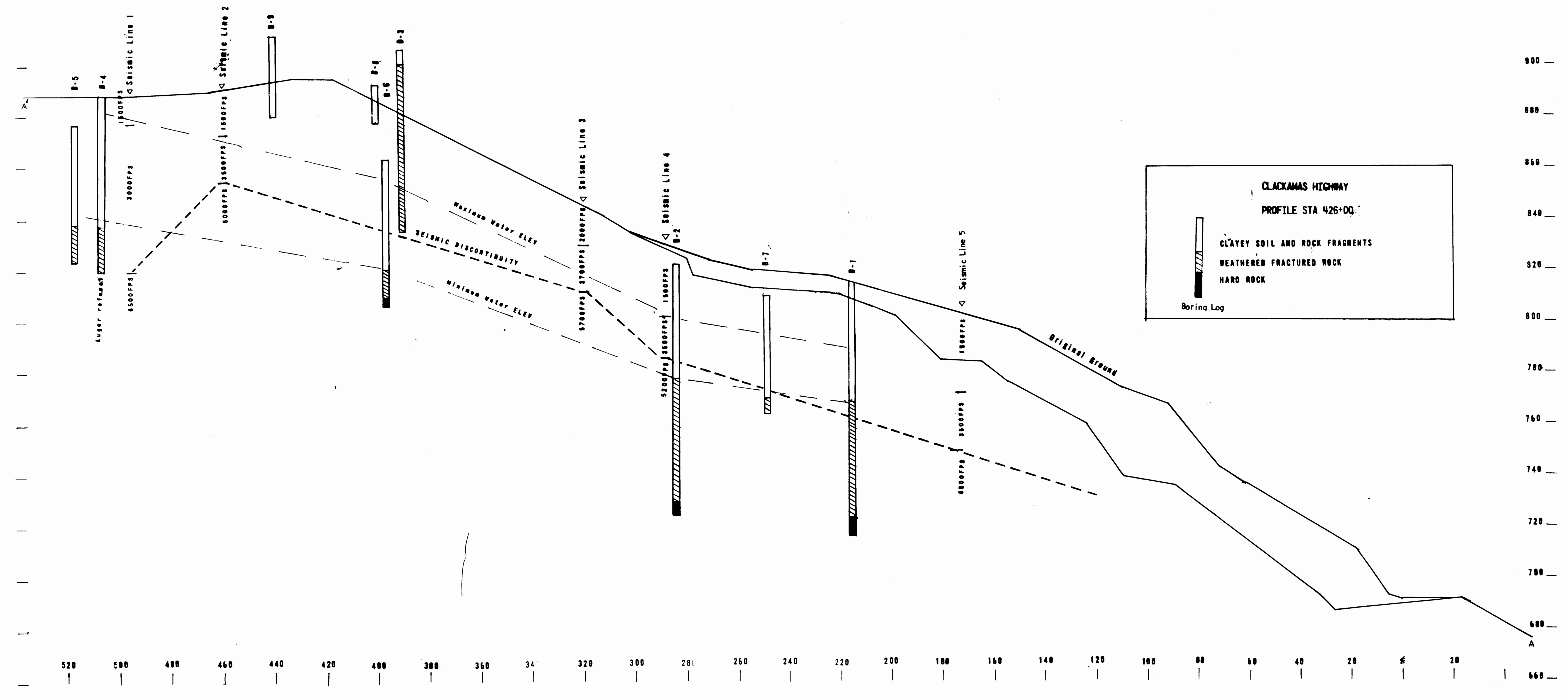

